\title{
OS JOGOS SOCIAIS NAS CIDADES DOS MEGAEVENTOS ESPORTIVOS: ETNOGRAFIA EM REDES E SOCIABILIDADES POLÍTICAS EFERVESCENTES, NO CONTEXTO DE PORTO ALEGRE-RS
}

\author{
Anelise dos Santos Gutterres ${ }^{1}$
}

\section{Introdução}

Esse ensaio tem a intenção de apresentar a experiência do trabalho com redes em uma pesquisa antropológica em contextos urbanos, de sociedades complexas, conforme as definições de Gilberto Velho (1987:17). O percurso traçado pelas questões que serão aqui apresentadas foi construído a partir do desenho, por parte da autora, de redes de negociação e de resistência no âmbito de uma concepção relacional entre, construções democráticas e sociedade civil, conforme nos aponta Marcelo Kunrath Silva (2006). No que tange a disciplina antropológica e as pesquisas em torno do fenômeno da cidade apresento a relevância das redes sociais para o fluxo de trocas - formador de vínculos políticos e partidários - no estudo do impacto de eventos como a Copa do Mundo em países como o Brasil, onde boa parte da população dos centros urbanos ainda vive sem acesso $^{2}$ aos recursos urbanísticos propostos pelos planos diretores de regulação do espaço citadino.

Que arranjos são realizados pelos atores para articular diferentes interesses num ambiente urbano em plena transformação? Como os espaços públicos, da forma como são pensados pelas leis urbanas, tencionam a vida cotidiana dos habitantes e colocam em riscos sua possibilidade de escolha diante de uma noção de trajetória social? Como se criam atores, mecanismos e rotinas em torno da vulnerabilidade de alguns sujeitos e cenários políticos?

Uma parte da rede, invisibilizada (Alfonsin, 2000) pela legislação urbana, viveria numa previsibilidade no que diz respeito as suas trajetórias de atuação na cidade e usufruto dela. Esses sujeitos estão constantemente ameaçados por rupturas e acelerações de desencaixes (Giddens, 1991) em suas rotinas à medida que as pleiteiam como agência da melhora em sua condição de vida na cidade. A forma como essas acelerações e rupturas são construídas pelos atores dos poderes públicos, responsáveis

\footnotetext{
${ }^{1}$ Universidade Federal do Rio Grande do Sul, Brasil.

2 De acordo com a Pesquisa Nacional por Amostra de Domicílios, realizada pelo IBGE, no período de 2001 a 2009, sobre a População Residente nos domicílios particulares (permanentes e improvisados), nas áreas urbana e rural, $52 \%$ da população do país possuía rede coletora de esgoto. Disponível em http://www.ibge.gov.br/home/ [acessado em junho de 2011].
} 
pela regulação da vida na cidade, são o ponto de partida para a constituição das reflexões sobre uma redes política e sua constante transformação à medida que os papéis sociais e o espaço da cidade também se transformam.

No âmbito da metodologia faço uso das coleções etnográficas (Eckert e Rocha, 2005; Rocha, 2008) que proporcionam e constroem um deslocamento temporal em razão das diferenças: de fontes, épocas e formatos - que os dados possuem entre si no interior de uma coleção. Nessa dinâmica é possível ter uma perspectiva da cidade a partir dos seus ritmos e da multiplicidade de dados produzidos sobre ela (Gutterres, 2010:201) ao longo dos anos. Em torno do método das coleções etnográficas as representações produzidas nos diferentes suportes não sofrem hierarquia uma sobre a outra e sim, estão sobredeterminadas por uma mesma imagem. Ou seja, a entendemos como oriundas de contextos heterogêneos, porém compostas por uma mesma formação inconsciente. Campo de força dessas coleções, a duração bachelardiana, conceito chave para o desenvolvimento de uma etnografia da duração "põe em evidência os conflitos dos instantes, dos ritmos sincrônicos que configuram o tecido temporal" (Eckert e Rocha, 2005:151) e esse princípio $^{3}$ proporciona pensarmos na continuidade e na sucessão temporal no seio da descontinuidade.

\section{O cenário da imprensa}

No fim do ano de 2010, as notícias sobre a copa do mundo no Brasil ainda não eram tão freqüentes. As informações ainda não tinham a forma da polêmica e pairavam sobre a construção e estudo dos projetos para a realização do evento, mais do que sobre obras em execução. A idéia de uma cidade transformada pela copa ainda estava na etapa de planejamento e anunciação e poucos jornais noticiavam o megaevento para além de seus editoriais esportivos. Os estádios, com exceção do Mineirão e do Maracanã, ainda estavam pouco transformados por demolições ou reformas. O Rio de Janeiro, como sede não só dos jogos da Copa do Mundo, mas das Olimpíadas de 2016 era naturalmente o município mais citado pela imprensa, nacional e internacional, quando a pauta eram os jogos. Acostumada a megaeventos a cidade havia sediado - apenas três anos antes - em 2007, o que foi classificado (Mascarenhas e Borges, 2009:2) como o maior evento

\footnotetext{
${ }^{3}$ Esse princípio é que orienta a construção de um acervo que reúne imagens de diferentes investigações acadêmicas ao longo dos 11 anos de existência do projeto BIEV, do qual essas orientações teórico metodológicas foram geradas. Para conhecer o projeto e os grupos de trabalho acesse www.biev.ufrgs.br [acessado em junho de 2011].
} 
esportivo da história não só do Rio de Janeiro como do Brasil, em termos de transformações e impactos urbanos, e claro, de despesas públicas.

Em termos de visibilidade jornalística, o Rio de Janeiro havia passado o fim do último semestre do ano de 2010 envolvido em manchetes internacionais que não tinham nada a ver com a copa do mundo de 2014, mas, já apontavam para algumas tensões que o evento poderia enfrentar. A fuga de centenas de jovens armados com fuzis, da Vila Cruzeiro, na Penha, em direção ao Complexo do Alemão, foi mostrada pela televisão com muita intensidade, gerando críticas do BOPE às empresas de comunicação. A ação estava indiretamente relacionada ao início da ocupação do Complexo do Alemão pela Unidade de Policia Pacificadora, as UPPs $^{4}$ nas favelas do estado e diretamente relacionada às queimas de veículos e ataques às cabines da PM pelos chamados “criminosos" durante o mês de novembro. A ação dos criminosos e a resposta da polícia ocupou por semanas o espaço dos telejornais ${ }^{5}$, onde especialistas, antropólogos, jornalistas, políticos, opinaram e discursaram sobre a questão da violência e da segurança pública no Rio de Janeiro nos mais diversos espaços midiáticos. A imprensa internacional impressa ${ }^{6}$ expressava preocupação com a proximidade do evento da copa ressaltando a "guerra contra o tráfico" em imagens que exibiam a polícia especial operando com a ajuda de tanques militares e helicópteros armados com fuzis. Em debate promovido por uma rede jornalística ${ }^{7}$ o ex-secretário de segurança pública do Rio de Janeiro, o antropólogo Luis Eduardo Soares, teria repetido o que afirmou em outra entrevista ao Observatório de Favelas "Eu tenho uma aposta, uma convicção pessoal de

\footnotetext{
${ }^{4}$ Segundo o atual Secretário de Segurança do Rio de Janeiro, José Mariano Beltrame, as Unidades de Polícia Pacificadora tem como objetivo "Recuperar para o Estado territórios empobrecidos e dominados por traficantes". A primeira UPP instalada na cidade do Rio de Janeiro foi no Morro Santa Marta, em 19 de dezembro de 2008. Segundo o IBPS, Instituto Brasileiro de Pesquisa Social sobre a avaliação da comunidade à instalação das unidades, realizada em janeiro de $2010,11 \%$ das comunidades e favelas pesquisadas - numa amostra composta de $44 \%$ de moradores da Cidade de Deus e 33\% da Batan disseram que as execuções diminuíram; 41\% disseram que os policiais do BOPE eram cordiais/corretos, no entanto, a pesquisa também aponta que $84 \%$ disseram que não tiveram contato com eles. Disponível em: http://upprj.com/wp/timeline.html [acessado em maio de 2011].

${ }^{5}$ http://www.jb.com.br/rio/noticias/2010/11/25/traficantes-fogem-da-vila-cruzeiro-durante-megaoperacaopolicial//http://www.band.com.br/noticias/cidades/noticia/?id=100000372109; http://www.youtube.com/watch?v=QK4b89m8m5Q; http://www1.folha.uol.com.br/cotidiano/835279-riotem-nova-madrugada-de-ataques-onibus-e-incendiado.shtml [acessados em janeiro de 2011].

${ }^{6} \mathrm{http} / /$ www.guardian.co.uk/world/2010/nov/25/rio-gun-battles-favelas-14-dead; http://www.elpais.com/fotogaleria/Lucha/Rio/alianza/narcos/elpgal/20101124elpepuint_2/Zes/6; http://www.lemonde.fr/ameriques/article/2010/11/29/des-narcos-seraient-en-fuite-a-travers-les-egoutsdes-favelas-de-rio_1446495 3222.html;

${ }^{7}$ http://www.tvcultura.com.br/rodaviva/programa/1232 e http://www.observatoriodefavelas.org.br/observatoriodefavelas/noticias/mostraNoticia.php?Section=5\&id content $=978$ [acessado em maio de 2011].
} 
que os eventos vão acontecer muito bem. Nós somos, afinal, ótimos em eventos. Mas a minha preocupação é com a rotina, com o dia a dia".

As obras da copa passaram o ano sem serem atualizadas ou eram pouco freqüentes nos noticiários locais. Haviam fatos mais envolventes acontecendo, entre eles o fenômeno Tropa de Elite 2 que levaria cerca de dez milhões de pessoas ao cinema para assistir uma encenação fílmica da disputa política sangrenta e violenta, que se passava justamente nas favelas cariocas. Alheio a esses acontecimentos, o site da FIFA ${ }^{8}$ era um dos poucos que veiculava a evolução das obras nos estádios esportivos, exibindo fotos de suas equipes e comitês em situação de inspeção. Apesar de usar expressões como: "um terremoto de obras no gigante" e "trabalhos a pleno vapor" - os objetos inspecionados não passavam de terrenos baldios, imensos buracos de terra escavada, às vezes, algumas demolições. Além dos estádios, as outras exigências da FIFA para a realização dos eventos: grandes avenidas, metrôs, BRTs (Bus Rapid Transit), modernos aeroportos; ainda continuavam em sua maioria, "no papel".

No Rio Grande do Sul o Temo de Compromisso entre: o governo do estado ${ }^{9}$, o município ${ }^{10}$ e os proprietários dos estádios esportivo ${ }^{11}$ com a sociedade Copa do Mundo FIFA 2014 - Comitê Organizador Brasileiro Ltda. ${ }^{12}$ foi assinado em dez de novembro de 2008. Neste documento - que retoma o contrato travado, no primeiro semestre de 2007, com dezoito cidades brasileiras ("host city agreements") - o tom é de cumprimento de prazos e definição de datas. Em um dos itens desse breve termo as partes se comprometem a entregar os estádios prontos (e conforme as exigências da FIFA) em 31 de dezembro de 2012, afim de que as "competições ${ }^{13}$ " possam ser realizadas.

Em outro Termo de Compromisso, agora entre: o governo federal no papel do ministério dos esportes ${ }^{14}$, o governo estadual, o município de Porto Alegre ${ }^{15}$, e o presidente do Sport Club Internacional, assinado em janeiro de 2010, as cidades sedes já

\footnotetext{
${ }^{8}$ http://pt.fifa.com/worldcup/news/newsid=1348380 [acessado em dezembro de 2010].

9 Representado na época pela governadora do estado do Rio Grande do Sul, Yeda Rorato Crusius.

${ }^{10}$ Representado, na época, pelo vice-prefeito Eliseu Santos.

${ }^{11}$ Vitório Carlos Costi Piffero e Emídio Marques Ferreira, respectivamente presidente do Sport Club Internacional e vice-presidente patrimonial do clube.

${ }^{12}$ Representado pelo seu Diretor-Presidente, Ricardo Teixeira, que esteve envolvido novamente, em maio de 2011, em mais acusações de corrupção ligadas a enriquecimento ilícito, recebimento de propina e formação de quadrilha.

${ }^{13}$ Ser escolhido como país sede envolve o compromisso com a realização de dois torneios: a Copa do Mundo e a Copa das Confederações.

${ }^{14}$ Representado pelo atual Ministro dos Esportes, Orlando Silva.

${ }^{15}$ José Fogaça, do PPS, recém re-eleito em segundo turno nas eleições municipais.
} 
não são mais dezoito, mas doze. E o estádio, já não é mais um estádio esportivo genérico, e sim o Estádio José Pinheiro Borda - "Beira-rio", que conforme o termo teve suas obras iniciadas em março de 2010.

É somente na chamada Matriz de Responsabilidade, firmada pelas três instâncias governamentais brasileiras - a federação, o estado e o município - que as responsabilidades aparecem nominadas em obras de/nos: "mobilidade urbana, entorno dos estádios, entorno dos aeroportos, entorno dos terminais turísticos e portuários, aeroportos - terminal de passageiros, pista e pátio - e portos - terminais turísticos".

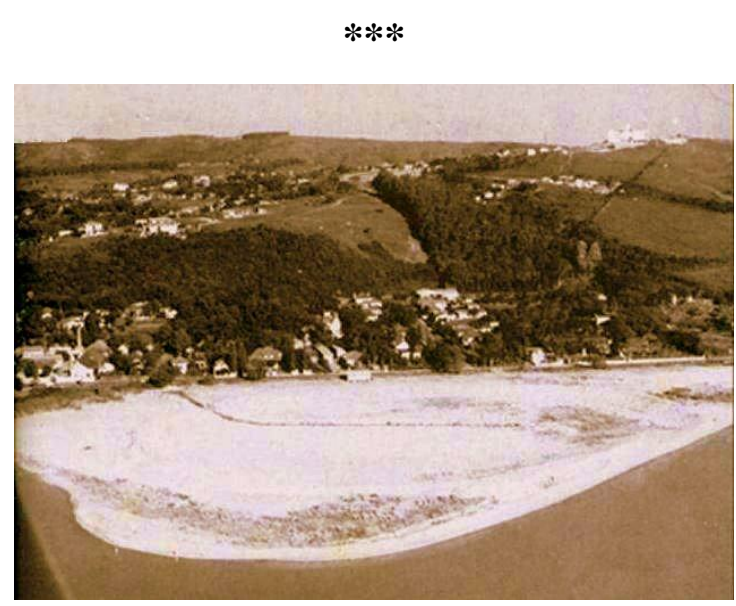

1. Foto do Morro Santa Teresa com detalhe da área a ser aterrada, no Rio Guaíba. Autor: desconhecido. Ano: aproximadamente 1956. Fonte: Acervo do Museu do Sport Club Internacional $* * *$

\section{O entorno dos estádios}

Construído entre 1959 e 1969, em uma área aterrada ${ }^{16}$, o estádio "Beira-rio" leva esse nome por estar localizado as margens do lago Guaíba. A área delimitada pela Matriz de Responsabilidades como "entorno dos estádios" corresponde, em Porto Alegre, a uma grande gleba verde composta de morro $^{17}$ - chamado Morro Santa Tereza uma grande avenida, pequenos comércios, uma escola privada, um asilo público, uma instituição estadual para menores infratores, uma escola de samba, e diversos tipos de unidades habitacionais, desde condomínios verticais na encosta do morro, prédios e casas de alto valor econômico, até moradias populares - a maioria sem registro de

\footnotetext{
${ }^{16} \mathrm{O}$ terreno onde está instalado o estádio foi doado pela prefeitura municipal de Porto Alegre antes mesmo do aterro ser realizado.

${ }^{17}$ Composta por uma Área de Preservação Permanente - APP.
} 
imóveis e sem saneamento básico promovidos pelo poder público. No total a região envolve pelo menos três bairros: Menino Deus, Santa Teresa e Cristal.

$* * *$

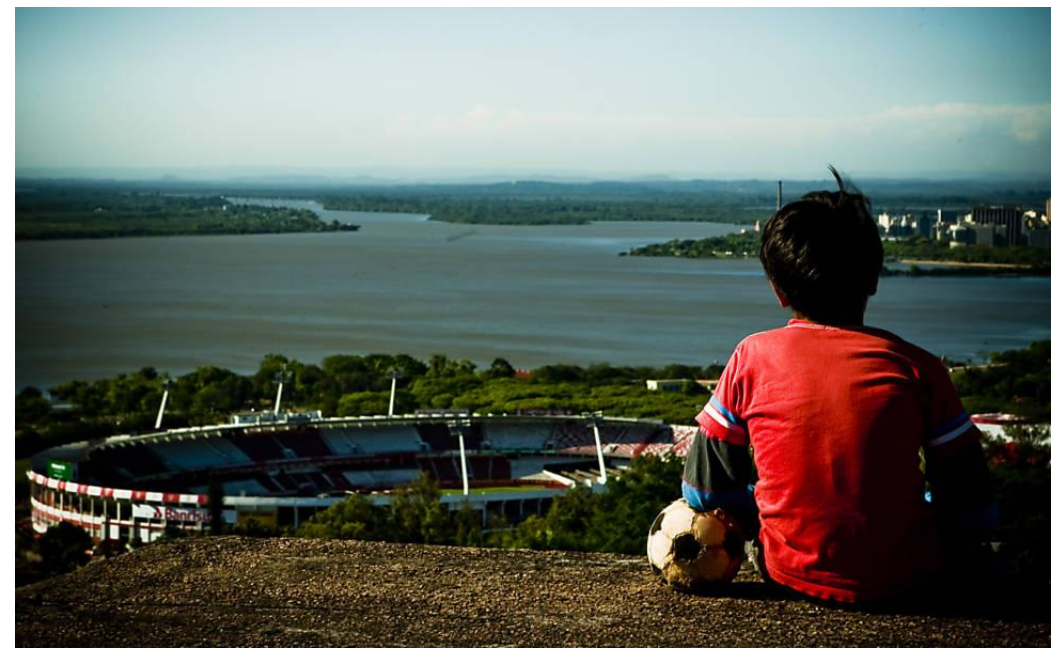

2. Foto panorâmica do Rio Guaíba, com detalhe do Estádio José Pinheiro Borda - Beira-rio, vista da Vila Gaúcha. Autor: Daniel Marenco. Ano: 2010. Fonte: Folhapress/ESPORTE, veiculada no especial Sedes da Copa de 2014, produzido pelo jornal Folha de São Paulo.

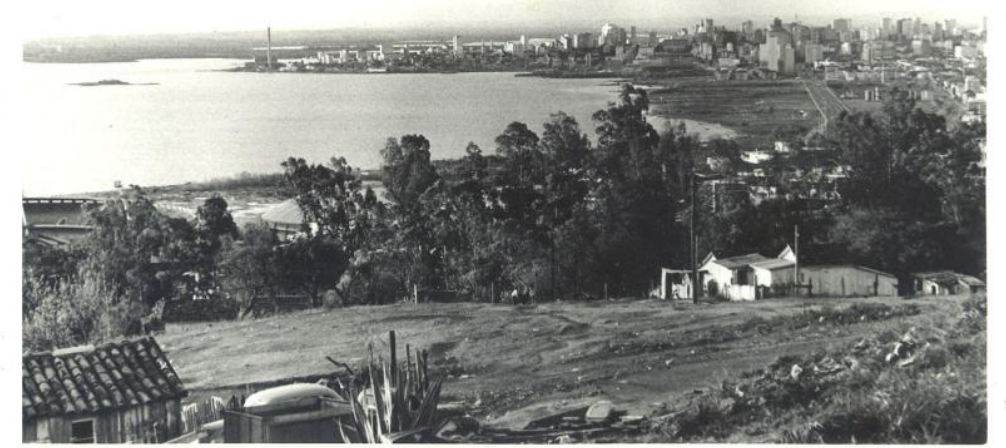

3. Foto panorâmica do Rio Guaíba, vista do Morro Santa Teresa. Autor: José Mauro Volkmer Castilho. Ano: 1974. Fonte: Acervo pessoal da família Castilho Volkmer.

***

Em 2007, em uma das encostas do morro, localizada no bairro Cristal, foi construído um museu para guardar a obra de um importante artista plástico, Iberê Camargo, levando o museu o seu nome. Quando apresentado o projeto desta obra teve grande discussão por parte da imprensa e arquitetos locais, pois situado como o estádio José Pinheiro Borda, à beira do rio, a construção tinha pouco mais do que algumas pequenas janelas. Essa "não exaltação" da paisagem do rio, num prédio à beira dele, 
teria soado como um despropósito pela classe média local. A paisagem natural, particularmente vinculada ao por do sol no rio, era amplamente reforçada pelas redes de camadas médias - através da memória coletiva - como um patrimônio da cidade.

Numa dinâmica da construção de uma memória ambiental ligada a orla, muito próximo ao museu há ainda uma área desocupada onde funcionava o estaleiro ${ }^{18} \mathrm{da}$ cidade, de propriedade da Família Só. A área desse estaleiro sofreu intensa discussão pública e disputa política, no ano de 2009, em torno de conflitos quanto ao uso desse espaço pela construtora que o teria comprado.

Em frente ao museu e ao lado do estaleiro, onde hoje há uma pequena praça, havia uma área intensamente ocupada por moradias irregulares, que a exemplo do que acontece com as habitações de camadas médias ${ }^{19}$ que existem ao longo da orla do Guaíba, isolavam o rio das vias públicas do entorno, privatizando seu acesso. O isolamento no caso dessa comunidade chamada de Vila Cai-Cai, no entanto, não era feito pelos imóveis e seus aparatos, mas pelo medo gerado pela idéia de violência e pobreza que a vila evocava. Removida na década de noventa (Sant'ana, 1997) o local é posteriormente transformado em área de lazer e segue com esse uso até a atualidade.

Entre o morro e o rio, passam duas grandes avenidas, Edvaldo Pereira Paiva, que costeia a orla, construída inteiramente sobre área aterrada e cujo nome homenageia o engenheiro que planejou as primeiras grandes perimetrais da cidade na década de 40; e a avenida Padre Cacique, cujo nome vem emprestado do já citado asilo, uma das primeiras construções da região, datada de 1898.

A trajetória de modificações na região foi se intensificando ao longo dos últimos cinqüenta anos. Nos últimos cinco, ela apontou para uma dinâmica de enobrecimento (Leite, 2010), que geralmente caracteriza as regiões que recebem grandes eventos como a Copa do Mundo.

A idéia de desenvolvimento, ao que parece também vinculada a este megaevento esportivo, vem promovendo reformas e transformações na cidade que tem a mesma didática da higienização do passado, vinculada a abertura de avenidas, a regulamentação de vias e normatização de construções imobiliárias. Todos adjetivos que costumeiramente andam ao lado oposto da noção de pobreza.

\footnotetext{
18 Sobre essa área denominada "Pontal do Estaleiro" e seus conflitos ambientais na produção de uma memória coletiva ligada ao patrimônio ambiental da cidade, ver o trabalho da pesquisadora Ana Paula Marcante.

${ }^{19}$ Ver minha dissertação de mestrado (Gutterres, 2010) e o conflito familiar em torno do terreno de uma antiga chácara de veraneio na região do Bairro Tristeza, localizada na beira do rio.
} 


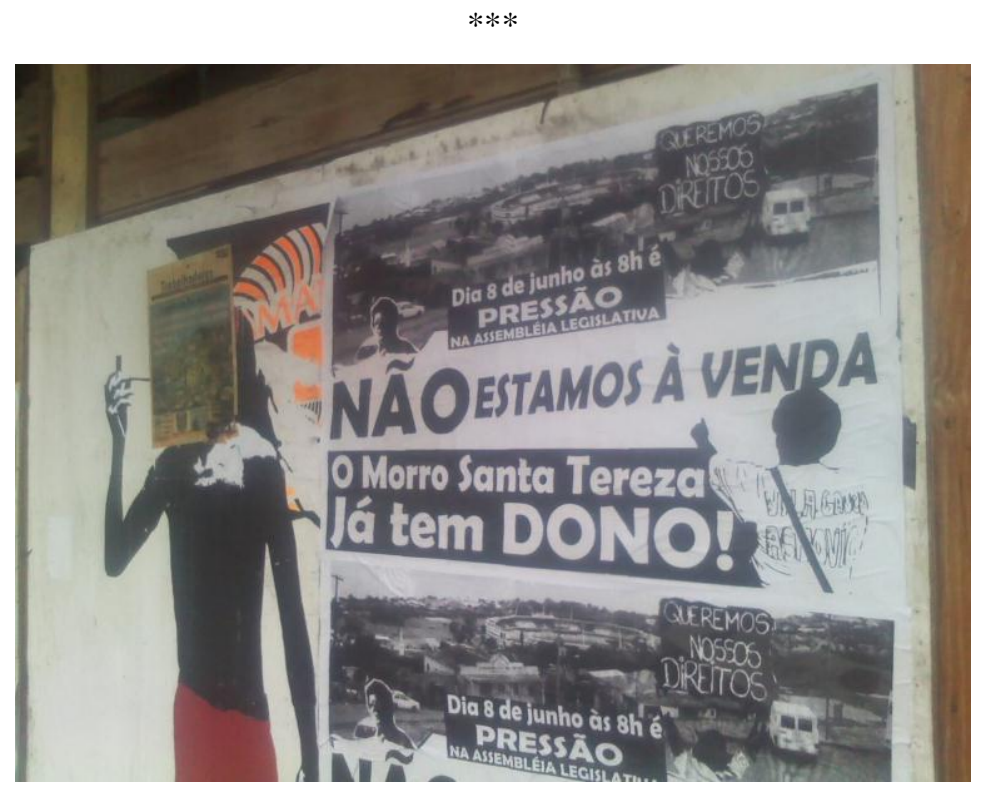

4. Foto de um cartaz divulgando o dia da votação da PL388 na Assembléia Legislativa de Porto Alegre, colado em um tapume no centro da cidade. Autor: Anelise dos Santos Gutterres. Ano: 2010. Fonte: Coleção Etnográfica A aporia da copa do mundo e as políticas de remoção de moradias: um estudo sobre conflito e memória.

\section{O morro é nosso}

No contexto dos movimentos sociais urbanos da cidade, o ano de 2010 havia sido paradigmático. O "caso do morro" havia rompido os limites: das redes universitárias ligadas as ciências humanas, da mídia alternativa, da rede política de sindicatos e lideranças locais, e da própria comunidade.

Podia-se ver cartazes colados nos postes, nos tapumes, "nas ruas", notícias nos jornais de grande circulação, e-mails com notas de repúdio vindo dos amigos mais engajados. Todos eles faziam referência a esse conflito, encabeçado pelo SEMAPI ${ }^{20}$, pelos moradores, movimentos e associações, tanto do próprio Morro Santa Teresa, como de regiões vizinhas.

\footnotetext{
${ }^{20}$ Sindicato dos Empregados em Empresas de Assessoramento, Perícias, Informações e Pesquisas e de Fundações Estaduais do RS.
} 


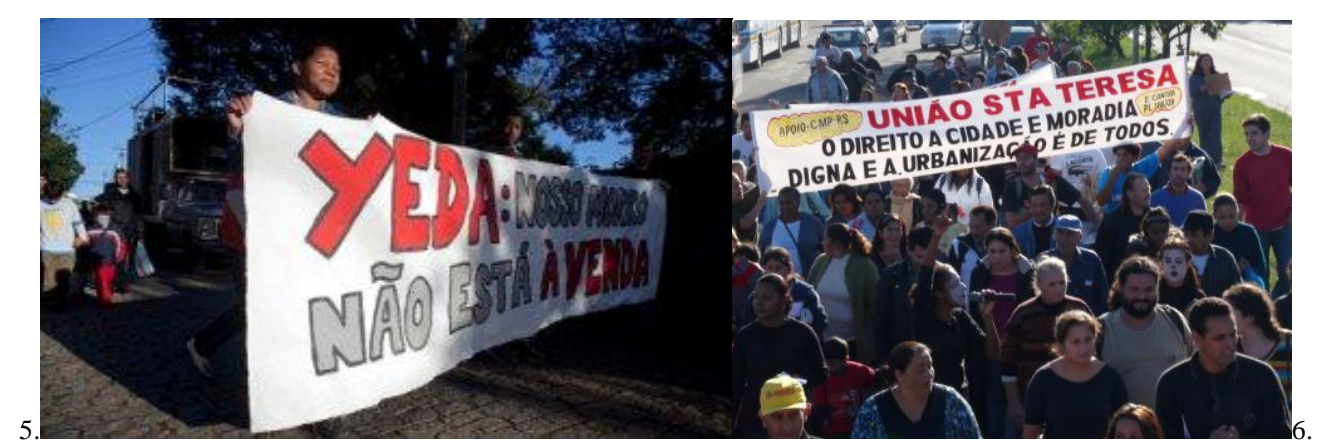

5. Foto da manifestação no centro da cidade contra o PL388. Autor: Eduardo Quadros. Ano: 2010. Fonte: Acervo PT Sul.

6. Foto da manifestação no centro da cidade contra o PL388. Autor: Leandro Anton. Ano: 2010. Fonte: Acervo Ponto de Cultura Quilombo do Sopapo.

A manifestação em defesa do morro Santa Teresa, conhecida como "o morro é nosso", ocorreu em meados de 2010, quando esse coletivo de sindicatos, indivíduos e grupos civis organizados, promoveu uma série de caminhadas, marchas, distribuição de cartazes pela cidade, criando um agitado movimento contra a venda da área de 74 hectares da $\mathrm{FASE}^{21}$, pelo governo do estado. Atendendo menores infratores a exFEBEM, virou $\mathrm{FASE}^{22}$ a partir de processos de adaptação ao Estatuto da Criança e do Adolescente - ECA - em 1990 e funciona no mesmo local sob essas novas exigências desde 2002. Essa instituição estadual, a exemplo do que ocorreu em outras regiões da cidade, como é o caso da antiga área industrial do quarto distrito, quando se instala, traz junto com ela seus funcionários e servidores, muitos deles, trabalhadores pobres, que ganham por parte dessa instituição a garantia de permanência na região. Muitos, somente com a palavra do antigo patrão como certidão de garantia, permanecem vivendo na área, hoje já densamente ocupada por moradores com diversas outras trajetórias sociais.

\footnotetext{
${ }^{21}$ De propriedade estadual a FASE é uma instituição para menores infratores que está localizado no Morro Santa Teresa. A manifestação era totalmente contra o projeto de lei 388/2009, publicado no diário oficial da Assembléia Legislativa em 14 de dezembro de 2009, "Autoriza a Fundação de Atendimento Sócio-Educativo do Estado do Rio Grande do Sul - FASE a alienar ou permutar imóvel situado no Município de Porto Alegre" com o objetivo de "usar os recursos obtidos com a alienação ou permuta do imóvel (...) à construção de unidades descentralizadas para a execução das medidas sócio-educativas de internação, conforme o disposto na Lei Federal nº 8.069, de 13 de julho de 1.990, Estatuto da Criança e do Adolescente".

http://proweb.procergs.com.br/Diario/DA20091218-01-100234/EX20091218-01-100234-PL-3882009.pdf [acessado em dezembro de 2010]

${ }^{22}$ De acordo com a Lei Estadual n 11.800 , de 28 de maio de 2002 e do Decreto Estadual no 41.664 Estatuto Social, de 6 de junho de 2002.
} 
Durante a mobilização para permanência no morro os integrantes do movimento personificavam o governo (Caldeira, 1984:207) na figura da governadora Yeda Crusius. Ela aparecia em frases como: "Yeda: nosso morro não está à venda", pintada em faixas que procuravam expressar ao poder público e sociedade civil sua recusa a comercialização do espaço. A exemplo de outros representantes políticos que ocuparam o mesmo papel de Yeda, ela adquiriu na memória política desse movimento uma expressão do tempo político que demarcou a trajetória de vida, ou seja, "de luta" dele. A idéia de tempo político, como já analisaram Caldeira (1984:272) e Palmeira (1996, 2001) tem na personificação uma estratégia de demarcação dos acontecimentos sociais, e como irão apontar alguns moradores da região, essa mobilização foi mais uma das ameaças sofridas por eles, e que pontua politicamente uma das etapas de sua sobrevivência na cidade. As ameaças de remoção e de deslocamento em massa realizadas pelo poder público, no caso de vilas e ocupações consideradas como irregulares, parecem andar sempre ligadas a grandes projetos (Alfonsin, 2000), grandes reformas envolvendo um interesse desenvolvimentista que como já foi dito, exclui a lógica da pobreza do espaço central da cidade. A noção de irregular de acordo com Maria Helena Sant'Ana reconhece “a inadequação quanto ao que é prescrito pelos códigos de edificação e urbanização reconhecidos e legislados pelo estado" (1997:64) legitimando a noção de centro. Essa noção, no entanto, opera como construção subjetiva quando pensamos nesse tipo de intervenção pública, ligada a melhorias e reformas urbanas, já que ela re-significa os espaços pelo intermédio da lógica econômica de comércio do solo urbano (Ferretti, 1984 e Souza, 2008).

Intensa, a mobilização em defesa do morro usava frases como: "Projeto da FASE, 20 mil moradores despejados”, “O morro Santa Tereza já tem dono!”, “Dia 8 de junho é pressão na assembléia legislativa", "Nós queremos morar onde sempre moramos" que ressaltavam tanto a ameaça de remoção vinda por parte do governo do estado, quanto a evidência dessa disputa em torno da ocupação do solo urbano, a partir do confronto entre esferas políticas distintas.

No dia oito de junho de 2010, na assembléia legislativa do estado, o projeto de lei foi retirado de votação, em meio a um auditório lotado de militantes, moradores, líderes comunitários, mediadores e representantes de sindicatos, que comemoraram a vitória do movimento frente ao governo do estado e principalmente frente à "especulação imobiliária" considerada a grande articuladora dessa lei. A frase "quando nós derrubamos a PL388" era freqüentemente citada por meus interlocutores como parte 
de uma narrativa de sucesso onde teria sido comprovada a força da luta onde "eles" - os inimigos - foram derrotados pelo "povo".
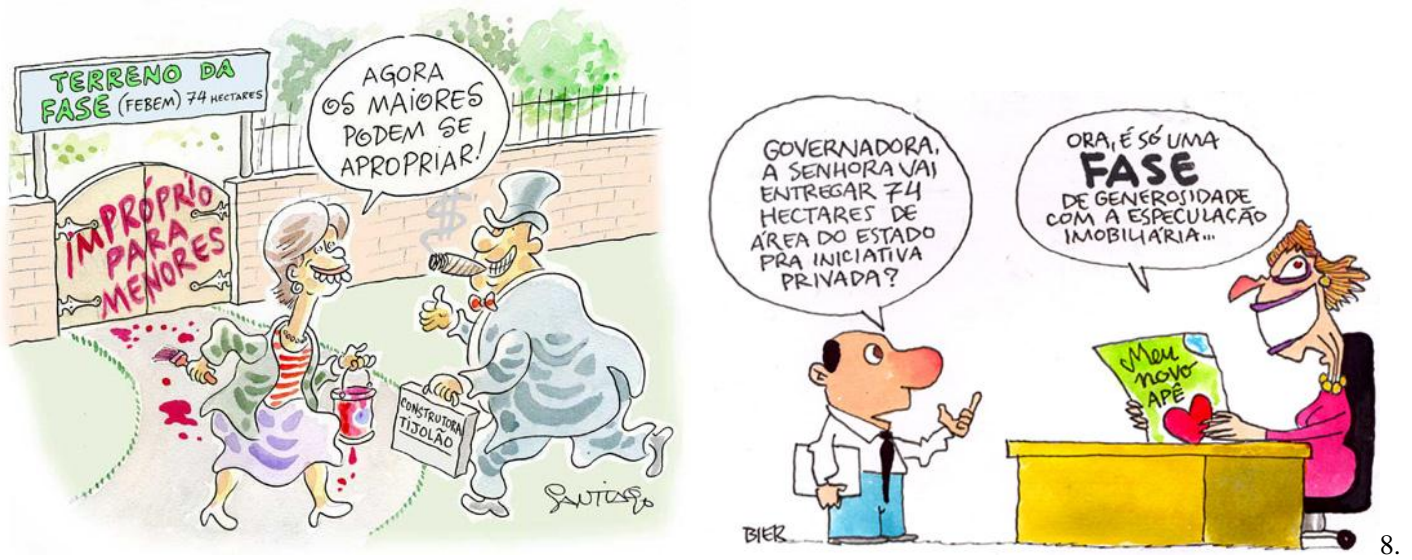

7. Charges. Autor: Santiago. Ano: 2010.

8. Charges. Autor: Bier. Ano: 2010.

Aproximando-nos da idéia de espaços imaginados, essas regiões seriam, então, o resultado do encontro entre, os "processos conceituais relacionados com a criação desses lugares e as alternantes condições econômicas e políticas” (Gupta e Ferguson, 2000:7) ali vividas.

O Morro Santa Tereza, ou simplesmente, "o morro" tornou-se uma unidade política e espacial em razão do processo de luta contra a venda de parte de sua área para a "iniciativa privada". Composto por seis vilas: Vila Gaúcha, Vila Prisma, Vila Figueira, Vila Santa Rita, Vila Ecológica e União Santa Tereza, o "morro" dá nome a um Bairro, homônimo. Heterogêneo o bairro é, também, composto por diversas empresas de telecomunicações e por moradias que conforme duas das maiores imobiliárias $^{23}$ da cidade têm um valor de venda que varia de $\mathrm{R} \$ 2$ milhões à $\mathrm{R} \$ 300$ mil Reais.

\footnotetext{
${ }^{23}$ Auxiliadora Predial http://www.auxiliadorapredial.com.br/Vendas/BuscaResultado.aspx?cidade=Porto+Alegre\&tipo=97\&bair

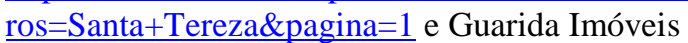
http://guarida.com.br/lista.php?tipoBusca=Comprar\&tipo=3\&cidade=PORTO+ALEGRE\&bairro[]=SAN TA+TEREZA\&dormitorio $=\&$ garagem $=\&$ min $\_$valor $=0 \& \max \_$valor $=\& l o c a l i z a c a o 1=\& l o c a l i z a c a 02=\& e n$ dereco $=\& \operatorname{codig} 0=\& \mathrm{x}=69 \& \mathrm{y}=16$ [acessado em janeiro de 2011]
} 
A categoria morro, no entanto, parece ser exclusiva para nominar as áreas das vilas, e ela é usada tanto para definir o caráter do movimento social gerado pela união das vilas em torno do objetivo comum de não venda da área pelo governo do estado e, também, como forma de evidenciar uma identidade ligada à geografia do morro, como um lugar de escarpas íngremes e do qual emerge a imagem de vila.

A região do Cristal, bairro vizinho ao Morro Santa Teresa, já havia sido alvo de conflitos fundiários no ano de 2008 e 2009, porém em razão de outro grande programa de transformação urbana. O bônus-moradia, no valor de 40 mil Reais, oferecido como contrapartida as desapropriações do Programa Integrado Socioambiental (Pisa) - que previa o re-assentamento de 1.680 famílias, segundo o divulgado pela prefeitura municipal - era freqüentemente trazido como alternativa negativa a qualquer comunidade que tinha sua condição de permanecer no local, ameaçada. O programa teve financiamento do Banco Interamericano de Desenvolvimento (BID), e incluiu recursos da Caixa Econômica Federal, contrapartidas da prefeitura e da empresa responsável por esse re-assentamento, o grupo Multiplan, proprietário do Shopping Barra Sul construído na área do antigo hipódromo da região.

A mera menção a proposta do bônus como contrapartida para abandono do local de moradia tinha como reação, revolta e indignação, como ficou evidenciado em um grande seminário sobre os megaeventos, o qual descreverei logo adiante, e onde participaram diversos líderes comunitários dessas e de outras regiões da cidade. Iniciado em 2008 os re-assentamentos da área do Cristal ainda não tinham sido concluídos e nem o pagamento do bônus-moradia aqueles que optaram por receber o dinheiro havia sido totalmente efetuado. As obras do PISA ainda estão em execução e as remoções realizadas na região não foram realizadas em sua totalidade. A possibilidade de remoção por intermédio deste bônus sempre retorna às narrativas dos líderes comunitários, que contam as histórias dos seus ex-vizinhos e parentes que não conseguiram comprar nenhum imóvel escriturado no perímetro da capital, por esse valor. E que a maioria havia gasto o dinheiro em aluguel e retornara a vila, ficando agora sem direito a nada.

Como o estatuto da cidade regulamenta e legitima, o tempo de moradia no local é importante para o direito à permanência no mesmo. Uma vez que o sujeito sai de sua casa, ou uma vez que o sujeito aceita uma contrapartida para sair de sua casa, ele fica vetado a participar de outro processo de financiamento a moradia. Conforme aponta Lomnitz (2001) no caso da formação da barriada Cerrada Del Condor na Cidade do México as redes de parentes são as principais agenciadoras da migração da parentela do 
campo para a cidade. Agenciando não só moradia, como trabalho e constituição de ofício, os vizinhos e os parentes são aqueles que viabilizam a vida na vila, às vezes muito insalubre e ilegalizada por conta desses processos contínuos de ameaça de remoção. No caso de Porto Alegre, alguns antigos moradores, em vistas do processo de remoção, se negam a ir para "o fim do mundo", preferem voltar para o interior, para sua família de origem, estabelecendo então o acionamento da rede, porém de forma inversa, da cidade para o campo ${ }^{24}$. Aqueles que não têm essa opção de rede acabam aceitando a remoção, mas não conseguem ficar por muito tempo no novo local. Alguns vendem as casas ou as alugam, retornando para junto das suas famílias, a uma condição de aluguel ou de sub - moradia, muitas vezes. Essa dinâmica de rede de ajuda mútua (Lomnitz, 2001) como constituinte da população das vilas, é freqüentemente ressaltada por parte dos líderes comunitários para provocar a reflexão dos moradores sobre a vida na lógica do loteamento que não dialoga com a vida na lógica da vila.

\section{O evento para discutir os eventos}

Os interlocutores o qual venho me referindo, conheci durante a participação no seminário "Megaprojetos e o Direito à Cidade", promovido pelo FERU/RS, Fórum Estadual da Reforma Urbana, que ocorreu nos dias dez e onze de dezembro de 2010, no auditório da Faculdade de Direito da UFRGS, em Porto Alegre.

O seminário "Megaprojetos e o Direito à Cidade" foi o último dos eventos promovidos pela ONG cidade no intento de refletir sobre os impactos dos grandes eventos nas questões de moradia e os conflitos decorrentes delas. O evento foi realizado em três turnos, no primeiro dia as atividades ocorreram à noite e no segundo dia, pela manhã e tarde. Ao todo foram dois turnos com apresentações de pesquisadores da área do direito, geografia e urbanismo, que relataram suas experiências e investigações para um público composto principalmente de lideranças comunitárias e militantes da causa da moradia na cidade; e um turno com relatos de integrantes da comunidade. No primeiro dia, a noite, um procurador da república expôs as conquistas que a democracia proporcionou no sentido da participação popular nos projetos e decisões do estado; e um geógrafo explorou as áreas atingidas pelas obras da copa do mundo em Porto Alegre. No segundo dia a tarde, um renomado pesquisador da Universidade Estadual do Rio de

\footnotetext{
${ }^{24}$ Ver o trabalho de Eunice Durham (1973) sobre migração de famílias do campo para a cidade, em meados da década de sessenta e sua relevância na formação das periferias e na constituição da cidade de São Paulo.
} 
Janeiro trouxe uma série de relatos sobre a experiência negativas da cidade com os Jogos Pan Americanos, citando, também, outras tantos exemplos de dívidas e exclusões, promovidas por essa espécie de eventos ao redor do mundo; um advogado alertou para as possibilidades de reação a algumas ações impostas pelo estado no âmbito da habitação; e um conhecido militante da causa da moradia, advogado que atuava na área de assessoria jurídica a movimentos populares que preferiu não estar a mesa. As falas dos especialistas eram seguidas de um momento onde todos da platéia podiam se dirigir até o microfone, a fim de darem sua opinião, seu relato, e externarem sua repulsa, principalmente relacionadas a distância entre os interesses "das comunidades" e do "poder público" e à corrupção do último. Esses momentos ocorreram por três vezes: no primeiro dia, após as falas dos pesquisadores, à noite; e no segundo dia após a fala deste pesquisador vindo do Rio de Janeiro, se constituindo como os instantes mais intensos do seminário. Contrastando com a fala calma e arrazoada dos palestrantes, a fala dos lideres comunitários e militantes tinham o tom da indignação. As pessoas que subiam até o pequeno púlpito, onde estava localizado o microfone destinado àqueles que gostariam de dar o seu depoimento, tinham que se inscrever na mesa principal para tal. Para se inscrever era necessário levantar o braço de modo que o mediador, sentado a mesa junto aos palestrantes, pudesse enxergá-lo. O mediador quase sempre olhava para o sujeito com o braço levantado, às vezes ao fundo, entre outros participantes e poltronas vazias e não hesitava em chamá-lo pelo nome "Luis, das Ilhas, ta inscrito, quem mais?".

A maioria dos mediadores e integrantes da platéia "eram macacos velhos" na militância de questões de moradia na cidade, e mesmos os mais novos eram conhecidos e reconhecidos entre si, como pude perceber nas interações pelos corredores e conversas paralelas entre os assentos, intensas durantes os dois dias de evento. Com essa dinâmica de inscrições todos os dois dias de seminário tiveram atrasos na finalização das atividades porque era intenso o fluxo de pessoas até o microfone. As falas sempre começavam com "boa tarde" ou "boa noite', cumprimentos à mesa, e seguiam num tom de injustiça, com colocações sempre muito veementes e bem embasadas. Era um grupo heterogêneo de pessoas, havia mulheres, homens, jovens, homens com mais de sessenta anos, negros, brancos e alguns que se apresentaram como descendentes de índios. $\mathrm{O}$ tom era de muita indignação em relação ao que "eles" estavam propondo para a cidade. Esse "eles" era por vezes associado a FIFA, por vezes associado às empreiteiras que "estavam de olho" na cidade, por vezes associado à câmara de vereadores, que 
modificava leis "no canetaço" sem o conhecimento da população, e por fim, "eles" era associado aos "grandes investidores" que estavam comprando a cidade, comumente nominados de "a especulação imobiliária". Os relatos evidenciavam um profundo conhecimento daquelas pessoas do funcionamento das esferas jurídicas e políticas do governo municipal, estadual e federal. Eles sabiam de quem era comprada a terra, para quem se deveria reclamar por ela, e também, como deviam reclamá-la.

O "caso do morro" e dos processos de bônus moradia no Cristal foram os mais citados no evento, e tornar-se-iam um exemplo de como a "pressão" podia dar certo. Esse resultado positivo aliado à idéia de êxito era uma garantia da continuidade do movimento e de reuniões e seminários como aquele.

\section{Seguindo as linhas: O que é o Fórum Estadual de Reforma Urbana?}

Em minhas primeiras reuniões do FERU/RS eu ainda confundia a produção do seminário com a existência do Fórum. Foram duas reuniões apenas que participei antes que o seminário ocorresse, de maneira que as redes de participantes do Fórum pareciam completamente emaranhadas para olhos da etnógrafa recém ingressa em campo. Nessas duas reuniões no qual estive presente participaram cerca de onze pessoas, oriundas de diferentes instituições e ligadas a diferentes áreas de atuação política e profissional. Quando falo áreas de atuação política me refiro à categoria "luta" que é como a maioria dos participantes se refere ao ser questionado sobre sua atividade. No blog ${ }^{25}$ do fórum, onde circulavam as informações, artigos e chamadas sobre acontecimentos relevantes para o grupo na cidade havia, também, uma série de informações que proporcionaram um entendimento mais abrangente, do contexto que envolvia a criação e o funcionamento dele.

Sediado na ONG Cidade, as reuniões do fórum ocorriam semanalmente e nelas se discutia as pautas trazidas por aqueles que participavam ativamente da reunião. $\mathrm{O}$ fórum era auto-gestionado e tinha como delegado na época de preparação do seminário, Sergio Baierle, que sempre que podia se esforçava em esclarecer sobre o caráter temporário dessa "coordenação" já que o objetivo do fórum era que as próprias lideranças comunitárias tomassem a frente da coordenação.

\footnotetext{
${ }^{25}$ Que pode ser acessado a partir de: http://reformaurbanars.blogspot.com/ [em janeiro de 2011]
} 
A ONG Cidade, integra o núcleo Porto Alegre ${ }^{26}$ de uma rede nacional formada por um instituto virtual de pesquisa e formação chamado Observatório das Metrópoles $^{27}$. Integrante do Instituto Nacional de Ciência e Tecnologia vinculado ao Ministério de Ciência e Tecnologia, o observatório das metrópoles teve sua origem no projeto de Avaliação da Conjuntura Social e do Desempenho das Políticas Públicas na Região Metropolitana do Rio de Janeiro, cujo objetivo era analisar as transformações do quadro de carências e desigualdades sociais na Região Metropolitana do Rio de Janeiro ao longo da década de 80 . Funcionando como um banco de dados que objetiva a comparação, o instituto pretendia identificar:

"tendências convergentes e divergentes entre as metrópoles, geradas pelos efeitos das transformações econômicas, sociais, institucionais e tecnológicas por que passa a sociedade brasileira nos últimos 20 anos"

Época da criação dessas organizações, o final da década de oitenta teve papel importante na construção de alternativas para gestão de problemas sociais no Brasil conforme ressalta Ferretti (1984) em sua análise do movimento social urbano em Porto Alegre e Alba Zaluar (1994; 2004; 2007) em seus extensos estudos sobre as categorias pobreza, trabalho e marginalidade no condomínio Cidade de Deus, no Rio de Janeiro. Em Porto Alegre e região metropolitana, nessa época se criou o Conjunto Habitacional Guajuviras, na região de Canoas, e que foi concluída a transferência de moradores de vilas na região do centro da cidade (Ilhota, Bairro Menino Deus, Praia de Belas e Santana) para o Bairro Restinga e, também, da Vila Tripa situada próxima ao Aeroporto Salgado Filho, para regiões adjacentes do Jardim Leopoldina ora denominadas Vila Safira e COHAB. Em 1973, a lei Complementar Federal número 14, criava a Região Metropolitana de Porto Alegre, reunido 14 municípios "que, já em 1967, haviam sido indicados como constituintes do que seria a primeira aglomeração metropolitana do RS” (FEEE, 2009:18). Esses municípios, criados entre 1846 e 1965, são em ordem de antiguidade: São Leopoldo, Gravataí, Viamão, Guaíba, Novo Hamburgo, Canoas, Esteio, Sapiranga, Estância Velha, Sapucaia do Sul, Alvorada e

\footnotetext{
${ }^{26}$ Em Porto Alegre, o núcleo está representado pelo Núcleo de Estudos Regionais e Urbanos (NERU), da Fundação de Economia e Estatística Siegfried Emanuel Heuser - FEE/RS. Além da FEE, o Programa de Pós-Graduação em Sociologia, o Programa de Pós-Graduação em Geografia, o Departamento de Urbanismo da Faculdade de Arquitetura, todos da Universidade Federal do Rio Grande do Sul (UFRGS). As atividades do Observatório das Metrópoles funcionam nas seguintes cidades: Porto Alegre, Goiânia, Belém, Fortaleza, Natal, Recife, Salvador, Belo Horizonte, Rio de Janeiro, São Paulo, Maringá. Oito dessas doze cidades será sede de jogos para a Copa do Mundo 2014, que junto a Cuiabá, Manaus e Brasília, formarão as doze cidades sede oficiais desse evento.

${ }^{27} \mathrm{http}$ ://web.observatoriodasmetropoles.net/index.php [acessado em janeiro de 2011]
} 
Cachoeirinha. Que foram acrescidos, em 1989 por Eldorado do Sul, Glorinha, Ivoti, Nova Hartz, Parobé, Portão e Triunfo, oriundos de desmembramentos e incorporações de cidades mais populosas. Esses e outros nove municípios agregados posteriormente, entre os anos de 1994 e 2001, totalizam uma área de $9.800 \mathrm{~km} 2$ com uma população de 3.718.778 habitantes (2009:22) que é a população total da grande Porto Alegre.

\section{A globalização do processo democrático}

No final dessa década é criada a ONG Cidade e também as primeiras pesquisas do Observatório das Metrópoles. A questão da migração para os grandes centros urbanos já havia construído grandes periferias, vilas e favelas, e com isso ia modificando a forma como o estado interagia com esses problemas. A autarquia DEMHAB, responsável pela política de habitação do município de Porto Alegre é resultado da re-estruturação do Departamento Municipal da Casa Popular, realizada em 1964 (Ferretti, 1984:124) uma exigência do Sistema Financeiro de Habitação, que também instituiria o BNH (Banco Nacional de Habitação) neste mesmo ano.

Formando uma rede transnacional de investimentos e pesquisa com foco nos estudos de cidade, esse instituto e a ONG passam a receber investimentos federais ligados a levantamento de dados e monitoria do crescimento urbano; e, também, internacionais $^{28}$ - ligados a categorias predominantemente colonizadoras, como sustentabilidade, participação, desenvolvimento, urbanização. Em uma das linhas de atuação da ONG podemos notar a presença de uma ideologia no que diz respeito à participação de sindicatos e movimentos sociais no cenário político governamental brasileiro, nessa época, também, recém democrático. Também se nota a preocupação com a autonomia das organizações políticas de base, de modo que a exigência de programas sociais com fundo estrangeiro exigia a participação popular como prérequisito para destinação de verbas. Essa exigência já era apontada como um risco a "normalização social” que seria o grande medo das organizações não governamentais e movimentos sociais, pois ela poderia transformar os movimentos em parte da estrutura político regular. Esse medo, conforme narraram alguns interlocutores, acabou se

\footnotetext{
${ }^{28}$ Segundo o site da ONG, desde 1990, ela conta com o apoio de diferentes instituições, o que tem garantido o desenvolvimento de suas linhas de pesquisa, entre eles Fundação Inter-Americana; Fundação Ford; Fundação MacArthur; KZE/ Misereor; Banco Mundial; ACDI - Canadá; IBP- International Budget Project; China Development Research Foundation/CDRF; CIMAS - Observatório Internacional de Cidades e meio Ambiente Sustentável/Universidade Complutence de Madrid; OXFAM/NOVIB; Transnational Institute/TNI; Universidade de Bradford - UK; Centro Universitário Metodista - IPA.
} 
concretizando com o fenômeno do orçamento participativo na cidade de Porto Alegre, no fim dos mandatos do partido dos trabalhadores no poder municipal.

Na esteira do fim das ditaduras na América Latina, o Brasil e Porto Alegre, com mais intensidade, em razão da criação do Orçamento Participativo ${ }^{29}$, receberam investimentos e sonhos de uma América re-democratizada, civilizada, e participativa na defesa das demandas urbanas e do uso do orçamento público. Visto que o processo de democratização e o ano de 1945 haviam produzido uma extensa área industrial, a crença em um cerco do Estado pela organização popular se esgotava, evidenciava-se "a natureza das novas lutas sociais e políticas colocava a necessidade de novas elaborações" (Fortes, 2001:22).

Segundo Fortes (2001:12) a abordagem do problema da agência histórica dos trabalhadores, como parte da sociedade brasileira, passaria então por uma mutação, assumindo a forma do debate sobre o que se convencionou chamar de "cidadania ativa". Para o autor o ano da campanha pelas eleições diretas para Presidência da República, em 1984, e o movimento pelo impeachment do presidente Collor em 1992, foram muito importantes para re-apropriação popular dos símbolos nacionais. O ano de 1992 teria redimido a "frustração dos veteranos de 1984 e 1989", mas mais do isso ele teria mudado a "relação dos movimentos populares com a estrutura político-institucional" (Fortes, 2001:20-23). Experiências de participação popular na gestão pública se disseminaram por todo o país, desde a adoção do orçamento participativo em prefeituras do PT até os conselhos de gestão partidária incorporados na Constituição de 1988. "Buscar seus direitos" seria uma expressão que indicaria a forte presença da idéia de que estes direitos seriam totalmente externos ao indivíduo. Por outro lado, porém, justamente esta materialização institucional do sindicato como canal de acesso aos direitos explica porque a luta por sua apropriação foi parte decisiva na construção da noção de cidadania operária no Brasil.

Esse ineditismo na "participação popular" em Porto Alegre é um argumento freqüentemente ressaltado e cobrado pelos atores que militam e atuam nas redes aqui expostas. A herança de uma "voz" que de fato podia inserir sua marca e o direito de escuta ao poder estabelecido atravessa os discursos dos participantes das reuniões às vezes com um tom de lamento por uma época onde esse sentimento era vivido mais do que uma saudade, como uma realidade. Em sua tese sobre segregação e a categoria raça, 
na Vila Condomínio Entrada da Cidade, em Porto Alegre, Jacqueline Pólvora (2006) ressalta o caráter internacional de Porto Alegre, porém não pelos motivos atuais, ligados a copa do mundo. A globalização da qual ela fala está relacionada ao evento do Fórum Social Mundial, em que Porto Alegre foi sede por dois anos. Uma das bandeiras que justificavam a cidade como sede desse evento estava relacionada com o sucesso do orçamento participativo e como ele havia se tornado uma experiência política compartilhada internacionalmente. $\mathrm{O}$ orçamento participativo é instituído no primeiro mandato do PT no governo municipal (Fedozzi, 2002; Silva, 2006) e, segundo Damo (2008:53) é internacionalmente o mais famoso deles por sua longevidade, publicidade e pioneirismo. Sua criação, sucedida da criação do FSM, ressalta a cidade de Porto Alegre no cenário mundial (Pólvora, 2006:56) como uma cidade onde a democracia era uma vanguarda mais ocidentalizada do que outras cidades de países 'subdesenvolvidos'.

O conceito de globalização (Schiller, 2007:449) aparece na rede pesquisada para dar conta de períodos de intensa integração através de sistemas capitalistas de produção distribuição e comunicação e seria o responsável pelas transformações na economia mundial e pela "hyper-absence" (2007:456) do estado. Nessa lógica da globalização e do caráter transnacional dos megaeventos, a crise das relações tradicionais de trabalho, possibilitou que alguns países conseguissem se integrar ao grupo das noções prestigiosas à medida que preenchessem requisitos de uma estética urbana e se sujeitassem a um sistema político global. A discussão política sobre colonialismo e pós-colonialismo é uma questão interessante em medida que ela influencia no modo como os grupos se relacionam com esses termos.

Na lógica de Bhabha (244-245) a perspectiva pós-colonial nos força a repensar as profundas limitações de uma noção "liberal" consensual e conluiada de comunidade cultural. Onde a cultura se torna uma prática desconfortável, perturbadora, de sobrevivência - entre a arte e a política; o passado e o presente, o público e o privado.

A América Latina, assim como a região sul do continente africano, vem experimentando um ingresso gradual na comunidade econômica global, e uma participação mais atuante em discussões a cerca de problemas "globais" auxilia no sentimento de pertença a categoria de "internacionalidade". O termo "internacional" remeteria a definição de modernidade como aquela capaz de apontar para a passagem do tempo, dividindo aqueles que ficam e aqueles que rompem, acelerando rumo à modernização (Latour, 1994). O "Moderno", para o autor seria “duas vezes assimétrico", pois ele "assinala urna ruptura na passagem regular do tempo; assinala um combate no 
qual há vencedores e vencidos". No contexto estatal brasileiro, a integração a categoria internacional, vinculada à modernidade promoveu inúmeras reformas urbanas, construções de subúrbios e pólos industriais tardios, ao longo dos últimos trinta anos. O "desenvolvimentismo" (Castro, 2002:239) iniciado na ditadura militar e seguido com novas roupagens até os dias atuais foi modificando as formas da cidade, e a circulação nela à medida que ia construindo espaços de amarração da memória que duravam na lembrança de alguns narradores, habitantes desses eixos hoje concretamente desaparecidos.

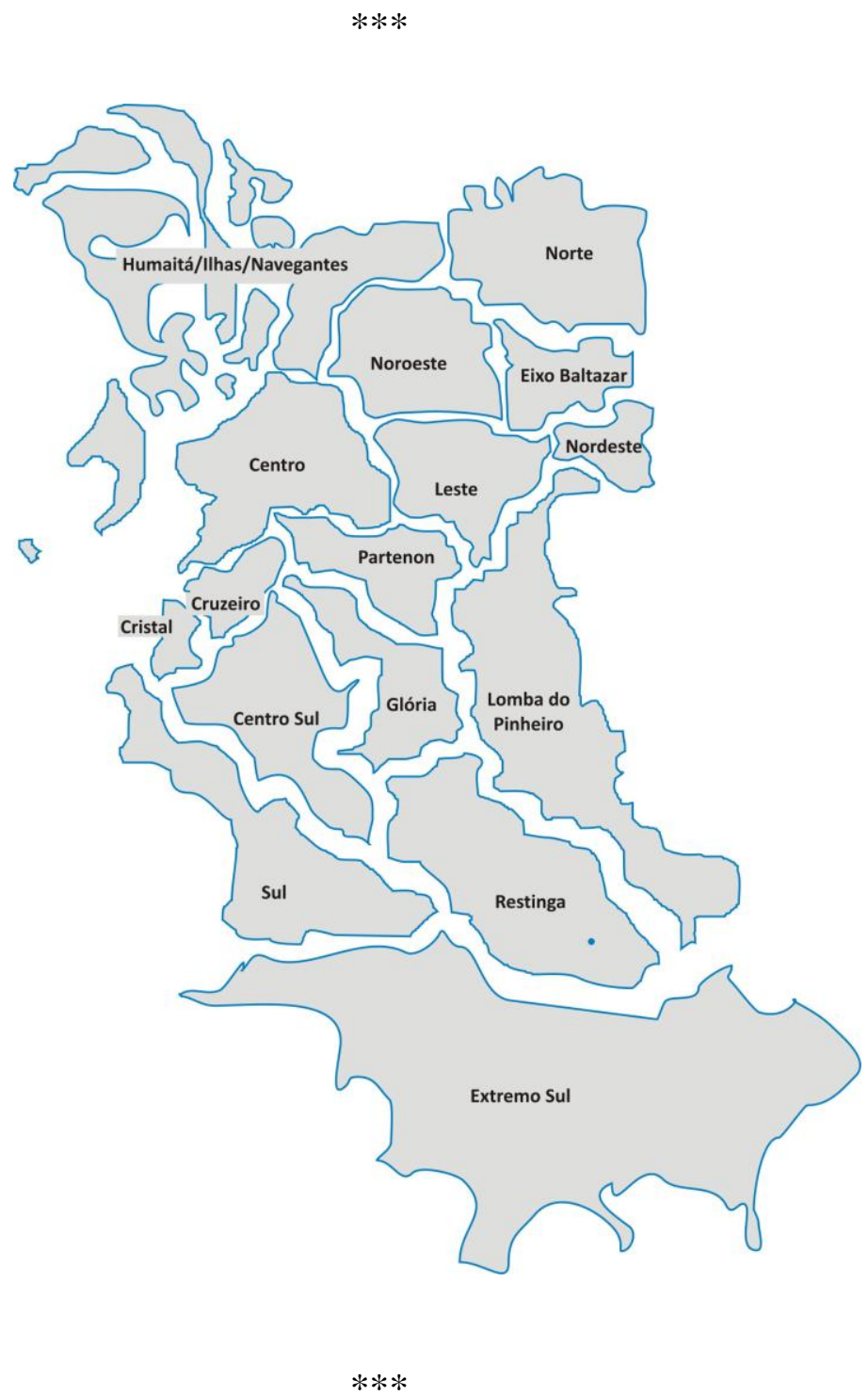

No âmbito do seminário, as oito regiões da cidade de Porto Alegre que reclamaram situações de conflito, em relação às obras instituídas como fundamentais 
para o bom andamento ${ }^{30}$ dos projetos para a Copa do Mundo 2014 na cidade foram: Nazaré/Dique (Região Noroeste), Morro Santa Tereza (Região Cruzeiro), Cristal, Ilhas, Humaitá, Orla, Restinga e Lomba. Três pontos pareceram contribuir para definição dessas regiões como grupos, pelos organizadores do FERU/RS. A primeira é que elas seriam atingidas pelas obras previstas para copa, direta ou indiretamente. A segunda porque elas são áreas vinculadas às regiões do OP (Orçamento Participativo), e, portanto, se organizam conforme essa definição político-espacial. E a terceira e principal das razões é a representatividade que tem cada uma das suas lideranças políticas junto ao FERU/RS e movimentos sociais.

Dessa forma as obras onde mais se nota conflito entre os moradores e o poder público - que ocorre por intermédio do município, o executor das obras - são: o corredor Moab Caldas (obra de Mobilidade Urbana ${ }^{31}$ ), a reforma do estádio Beira Rio (Estádio José Pinheiro Borda) e ampliação do Aeroporto Salgado Filho (aeroportos e portos). Obras que atingem diretamente a região das vilas do bairro Cristal e Cruzeiro e as Vilas Nazaré e Dique, no bairro Anchieta.

\section{"Eles" e o público transfigurado}

Foco de transformação, zonas localizadas em torno dos estádios ${ }^{32}$ ou no local das futuras obras de mobilidade a eles: as vilas do bairro Cruzeiro e Cristal, o norte do bairro Humaitá e o centro do bairro Anchieta - onde fica a área do Aeroporto

\footnotetext{
${ }^{30}$ Criada no final de 2008 a SECOPA - Secretaria Extraordinária da Copa - tem como objetivo (em parceria com as demais secretarias municipais) a preparação de Porto Alegre para a Copa do Mundo de 2014. Quase extinta em 2011, a SECOPA é constituída de Comitê Organizador que atua em sete eixos temáticos: Mobilidade Urbana, Turismo e Rede Hoteleira, Marketing e Eventos, Infra-estrutura Esportiva, Meio Ambiente e Sustentabilidade, Voluntariado, Capacitação profissional e Protocolo, Promoção Comercial, Tecnologia e Serviços Públicos. Coordenada por João Bosco Vaz (PDT) desde janeiro de 2011, ano do primeiro mandatos dos governantes eleitos em 2010, a secretaria antes era presidida pelo exsecretário municipal de Planejamento, Ricardo Gothe.

Www.seconpapoa.com.br [acessado em fevereiro de 2011].

${ }^{31}$ Segundo o governo federal sob a responsabilidade da Controladoria-Geral da União (CGU), as obras de mobilidade urbana serão o grande legado da Copa para as cidades brasileiras, sedes do evento. O corredor Moab Caldas, terá 3,4 quilômetros e irá abranger a região de quatro bairros: Cristal, Cruzeiro, Medianeira e Santa Tereza. Com verba advinda do Ministério dos Esportes a execução da obra será feita pelo município. A obra custará R\$ 133,60 milhões de Reais dos quais R \$ 4,30 milhões, serão destinados as desapropriações. A maior parte da obra será financiada pela CAIXA federal, através das operações de crédito SUSAN - Superintendência Nacional de Saneamento e Infraestrutura - do Programa PróTransporte PAC Copa 2014, do qual R\$ 71.680.638,00 já estão financiados, e dos quais R \$ 6.805.263,16 virão de uma contrapartida por parte do município. Com garantias de contrato niveladas pela receita do ICMS - Imposto sobre circulação de mercadorias e prestação de serviços - o município tem até 22 de março de 2034 para pagar a dívida. Em fevereiro de 2011, a fase de levantamento sócio - econômico que avalia as estratégias de desapropriação e re-assentamento de famílias habitantes das bordas da avenida, e que é exigido pela financiadora para liberação da verba, ainda não havia iniciado.

${ }^{32}$ Estádio do Sport Clube Internacional e do Grêmio Footbal Portoalegrense, que não receberá jogos, mas será campo de treinamento oficial (COT) das equipes que jogarem em Porto Alegre.
} 
Internacional Salgado Filho - ganham uma perspectiva de centro com a iminência da copa. Concomitante, pelo direcionamento de grandes somas de dinheiro para essas regiões e pelo vínculo imediato a um evento globalizado como a Copa do Mundo, a categoria centro torna-se evidência de sua própria dinâmica e sazonalidade. Porém não só ela. Notei que à medida que essas áreas começaram a ser alvos de investimentos de caráter central, como: ampliação, sinalização e pavimentação de avenidas, saneamento, e divulgação da idéia de re-urbanização, o caráter público revelava nuances que até então não podiam ser notadas ou, não eram aparentemente tão descontínuas.

Em uma manifestação organizada pelo movimento "o morro é nosso" e por uma das associações da vila cristal, na avenida tronco, em fevereiro de 2011, se reuniram cerca de 200 moradores. No curso da caminhada, que promoveu o bloqueio da avenida para carros e ônibus que ali passavam, os moradores e líderes comunitários propuseram uma parada nos arredores do ponto onde, pelo projeto de ampliação da avenida, será construída uma praça. Nessa ocasião pude conversar com algumas moradoras da região que atraídas pela voz de um dos líderes ao microfone, haviam saído para o lado de fora de suas casas. Habitantes de um beco com umas 30 casas, elas reclamavam principalmente da precária instalação de luz, da umidade e dos alagamentos constantes, no acesso as suas casas. Ao fazerem as reclamações, essas mulheres usavam "eles" para se referirem àqueles que não haviam lhes dado ouvidos, eles, os governantes do município. Elas alegavam que moravam ali há anos e a há anos solicitavam melhorias, obras de esgoto e calçamento: "se eles arrumassem seria ótimo ficar aqui né, eu até queria uma casa melhor, essa aqui é muito úmida, e todos esses fios ai, olha só". A mulher falava e apontava para uma caixa de madeira com o número 128 escrito com tinta branca a qual em cima se emaranhavam dezenas de fios de luz, em torno de um pequeno poste de concreto. "Eles querem fazer uma praça aqui, é isso? A gente sabe né, que vai ser bom para a cidade, é um progresso né? Mas, como nós vamos ficar aqui? Como é que é, Pitinga, né? Como é esse lugar que querem nos levar? Eu nem sei onde fica, e aqui é tão perto do centro, da escola das criança. Passa o ônibus aqui na frente, ó" apontando para o ônibus Pereira Passos que nesse momento entrava pela avenida quase nos derrubando de cima de um recuo de barro que dividia a pista da entrada das casas. Mari, que na verdade se chamava Maria Inês, segurava uma criança no colo, assim como as outras duas das quatro mulheres com que eu conversara, logo após a manifestação. Ela falava comigo parada em frente seu beco e concluíra pouco antes de 
nos despedirmos: "Bem que Eles podiam arrumar né? Pra que uma praça aqui? Vai encher de maloqueiro!" fazendo referencia a futura obra que ali seria realizada.

A idéia de público referida, por Mari, através do direito de instalação de serviços como: posto de saúde, escola e saneamento; é diferente da imagem de público, promovido pela iminência dessas obras. As obras extrapolam a experiência cotidiana dos moradores em requerer "melhorias" para a região, que como direito de habitantes da cidade eles teriam. Agora a cidade é maior que eles, e eles devem colaborar com o público, deixando que outras "melhorias" sejam feitas para o bem de uma cidade mais funcional, mais moderna e internacional. Cotidianos que então recebiam destaque pelo discurso da violência, da drogadição e da pobreza, começam a ingressar numa outra lista, a da humanidade, da dignidade e dos direitos humanos. Deslocados, transferidos e re-assentados esses sujeitos integram a bonita história das modificações rumo à cidade do futuro.

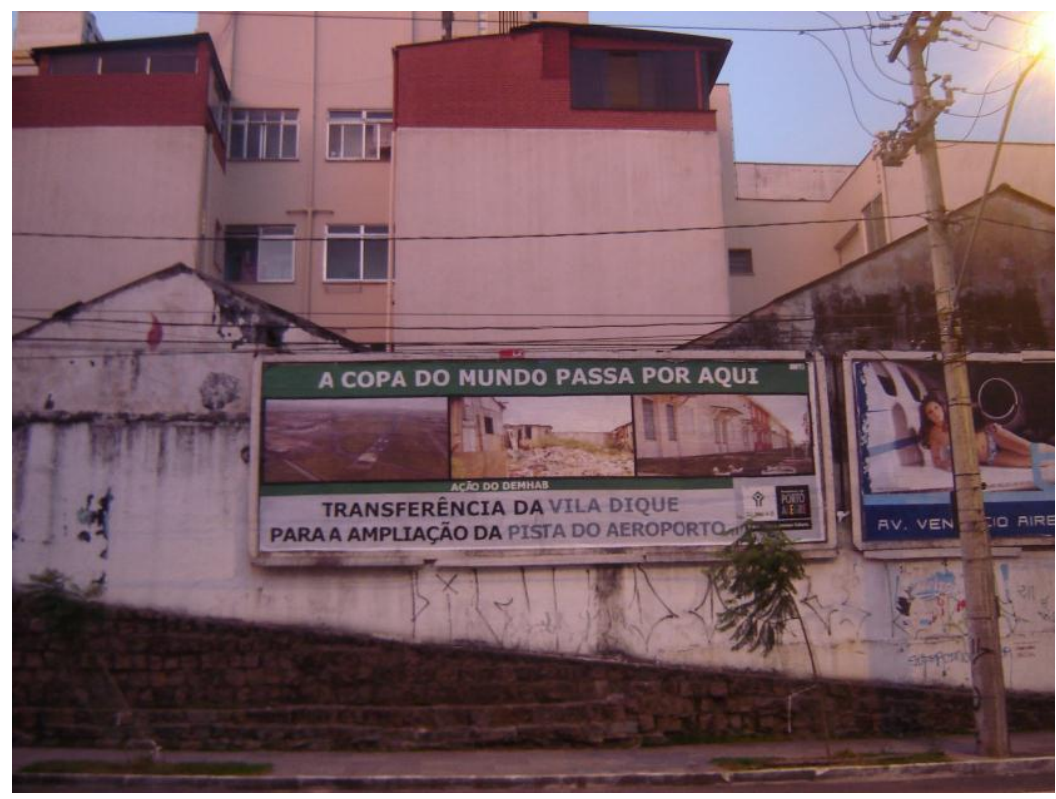

9. Foto de um cartaz divulgando o dia da votação da PL388 na Assembléia Legislativa de Porto Alegre, colado em um tapume no centro da cidade. Autor: Anelise dos Santos Gutterres. Ano: 2010. Fonte: Coleção Etnográfica A aporia da copa do mundo e as políticas de remoção de moradias: um estudo sobre conflito e memória.

São os moradores, mas também são aqueles que integram as redes de discussão política, e que estão e tem ligação direta com departamentos e comitês vinculados ao governo do estado e governo municipal e também federal, que fortalecem esse discurso 
marginal contra o estado que não lhes atende como deveria e que agora quer lhes tirar o pouco que foi adquirido. Um discurso produzido nessa lógica é a letra de Rap abaixo transcrita e que foi tocada para os participantes tanto no último dia do seminário, quanto na manifestação narrada acima, junto à avenida tronco.

\footnotetext{
Depois de 15 anos morando aqui, sol nasceu sol se pôs, quantas vez curti Incontáveis dias, milhões de perspectivas

Interrompidas, falidas, nego Eti conta a fita

O meu endereço é descartável nesse estado, corrupto e empreitista do mercado imobiliário

A vassoura capitalista judia quando passa por aqui, é certo

Não vai sobrar quebrada, não vai sobrar buteco, e o resto?

Me diz o que será? Só lembranças, muita histórias para contar

Esse é o lugar, com data programada na agenda do Fogaça para sumir do mapa Crianças descalças nas ruas de terra, quanto custa a urbanização da favela?

É a pergunta do Sequela, empreiteiros do governo, são falsos feiticeiros com montanhas de dinheiro

Para eles não é nada, não faz falta pagar, 40 mil e mandar os pobres caminhar,

Vazar, procurar outro lugar pra morar, simplesmente pra deixar o playboy do Barra Shopping sossegado pra estacionar ${ }^{33}$
}

Em sua letra, os autores ressaltam que a vila ficou "esquecida" até que chegassem os "falsos feiticeiros" produzindo a lembrança de que aquela área poderia render "montanhas de dinheiro", a partir do descarte do endereço daqueles que moravam ali. Na letra se evidencia a temporalidade de um ciclo e uma aceleração no desencaixe do tempo que não fixa essas "quebradas" num mesmo lugar por muito tempo. A letra leva um tom de "ah, fui novamente encontrado!" e a "vassoura capitalista" vai passar por aqui para levar quem é pobre. As melhorias serão feitas, mas, de novo, em outro lugar.

A dinâmica desse outro lugar, como um lugar afastado do centro, problematiza essa relação. O condomínio da entrada da cidade, por exemplo, um loteamento realizado pelo PT (Pólvora, 2006) estava construído em uma região limítrofe, ao centro. Hoje com a construção do estádio Arena do grêmio, esse loteamento passa a ser central nas questões de mobilidade urbana e segurança para circulação de estrangeiros na região.

Seu Darci, líder comunitário e presidente da associação da Vila gaúcha, sempre que pode justifica que as múltiplas remoções levadas para um lugar comum "são um barril de pólvora". Ele diz isso justificando as diferenças entre as origens e as trajetórias de cada ocupação, de cada vila, e a relação com o local de trabalho, geralmente em

\footnotetext{
${ }^{33}$ Parte da letra da música 40.000, escrita pelo rapper Doido Pelota e gravada no RAP Studio. O clipe da qual a música foi transcrita está disponível no site www.youtube.com e tem direção de Josías Salvaterra.
} 
torno de onde se mora. Dando o exemplo da remoção da vila cai-cai - conforme já citado anteriormente, uma ocupação que estava localizada a beira do Guaíba, junto a Avenida Edvaldo Pereira Paiva - para o Loteamento Cavalhada, zona Sul da cidade, onde já existiam vilas oriundas de outras regiões da cidade Seu Darci diz: "levam as pessoas tudo para lá, e ai vira um barril de pólvora, começa todo mundo a roubar todo mundo, não tem mais respeito, é isso que eles vão fazer, vão criar verdadeiros barris de pólvora", conclui a liderança.

A lógica da unificação, da remoção e da "melhoria" nas condições de moradia é promovida no presente, dentro dos planos nacionais de habitação ${ }^{34}$, pelo programa federal de incentivo ao crédito à moradia: Minha Casa Minha Vida. O velho "sonho da casa própria" aparece nesses programas como uma alternativa digna e viável a “populações de baixa renda" (Sant'Ana, 1997 apud Metroplan, 1982) na maioria das vezes excluindo lógicas intermediárias ligadas a heterogeneidade das trajetórias sociais dos habitantes em favor da premissa da pobreza e da marginalidade, que pela via da normatização das habitações seria finalmente solucionada.

$$
* * *
$$

\footnotetext{
${ }^{34}$ Há uma longa trajetórias de programas instituídos pelo poder público, com o intuito de promover acesso ou financiamento a habitação desde a implementação do BNH, em 1964. Entre eles podemos ressaltar o Projeto Cura e O Pró- gente ambos da década de setenta. Para uma relação desses planos dentro de uma política de planejamento urbano em Porto Alegre ver os trabalhos de Ferretti, 1984; Alfonsin, 2000; Nygaard, 2005; e Souza, 2008.
} 


\section{Moradores e Líderes Comunitários}
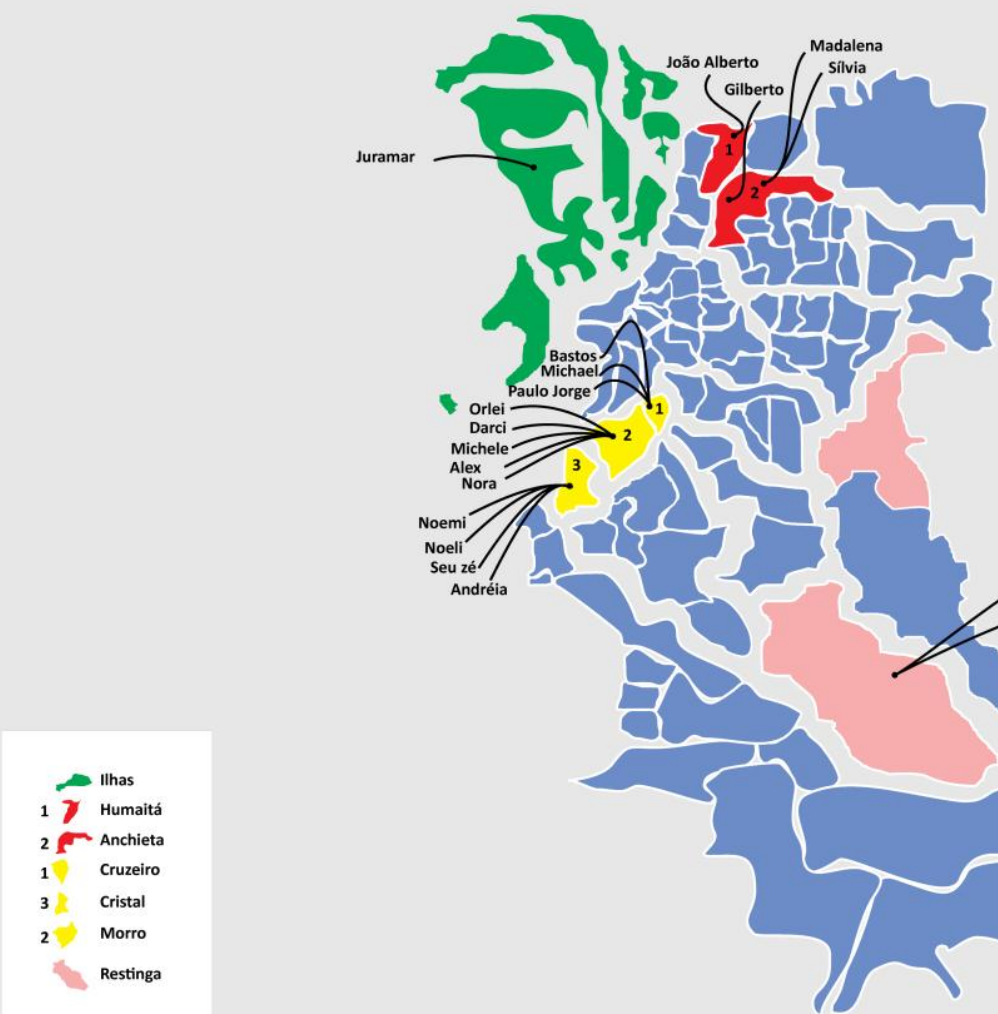

$7_{3}^{2}$ 
que são vilas muito diferentes, na forma, na trajetória de ocupação e também no que eles chamam do "socioeconômico", que é o dispositivo metodológico utilizado pela prefeitura para construção do perfil sócio econômico de regiões em áreas de remoção ou urbanização. Esse levantamento, que usa parâmetros como: descrição do domicilio, recebimento de recursos assistenciais, tipo de ocupação, tamanho da família, se possui cavalos, acesso a serviços, tempo de moradia e participação em associação de bairro, estava sendo aplicado na população da área da avenida tronco, e já havia sido realizado por duas vezes (2007 e 2009) na Vila Nazaré, que apesar de constar como projeto prioritário pelo DEMHAB (2009) ainda não havia sido removida.

Esse mapa coloca em evidencia a representação política do espaço de abrangência das regiões dos orçamentos participativos em relação aos espaços, dos bairros, vilas e becos, que cada um dos integrantes acima apontados, mora e faz parte. Esses moradores, alguns líderes comunitários, são considerados os "integrantes da comunidade" do ponto de vista da estrutura do evento. Foram eles que tomaram o púlpito exigindo esclarecimentos dos programas públicos de habitação, da apresentação dos projetos ligados a copa do mundo e que atingiriam suas vilas e bairros e foram eles que expuseram os problemas conforme eles apareciam em seus cotidianos. O restante dos integrantes, conforme a rede montada abaixo, é integrante de conselhos, comitês, organizações, instituições ou são profissionais que militantes na causa da habitação, integram a categoria "luta" junto com os moradores. Nem todos os atores que aparecem indicados no mapa, que destaca as áreas onde ocorrerão obras relacionadas a copa do mundo e portanto áreas que estão sendo etnografadas pela pesquisadora, compareceram no seminário e reuniões do FERU/RS. Nesse sentido, a montagem dela proporcionou uma reflexão sobre as múltiplas camadas políticas que envolvem a construção de um modelo de atuação entre instâncias governamentais e não governamentais. Longe de representar uma totalidade da estrutura política em suas diferentes esferas, aberta e infinita (Barnes, 1987) a rede é um recorte e um percurso que sobrepõe todas essas esferas e instâncias de participação e envolvimento político a partir de uma experiência comum, a do seminário.

A partir da legenda e de suas diferentes colorações podemos ler a relação entre as associações, os movimentos e suas interconexões (Barnes, 1987:171) e como eles se formam. A forma apresenta as conexões e os vínculos políticos, entre o município - no papel dos conselhos; dos não institucionalizados - no papel dos movimentos e ONGs; dos sindicatos e associações de classe; das associações de moradores; e entidades 
financiadas pelo governo federal, como é o caso do projeto cultural de "inclusão social", Ponto de Cultura Quilombo do Sopapo, mantido com verba do Ministério da Cultura.

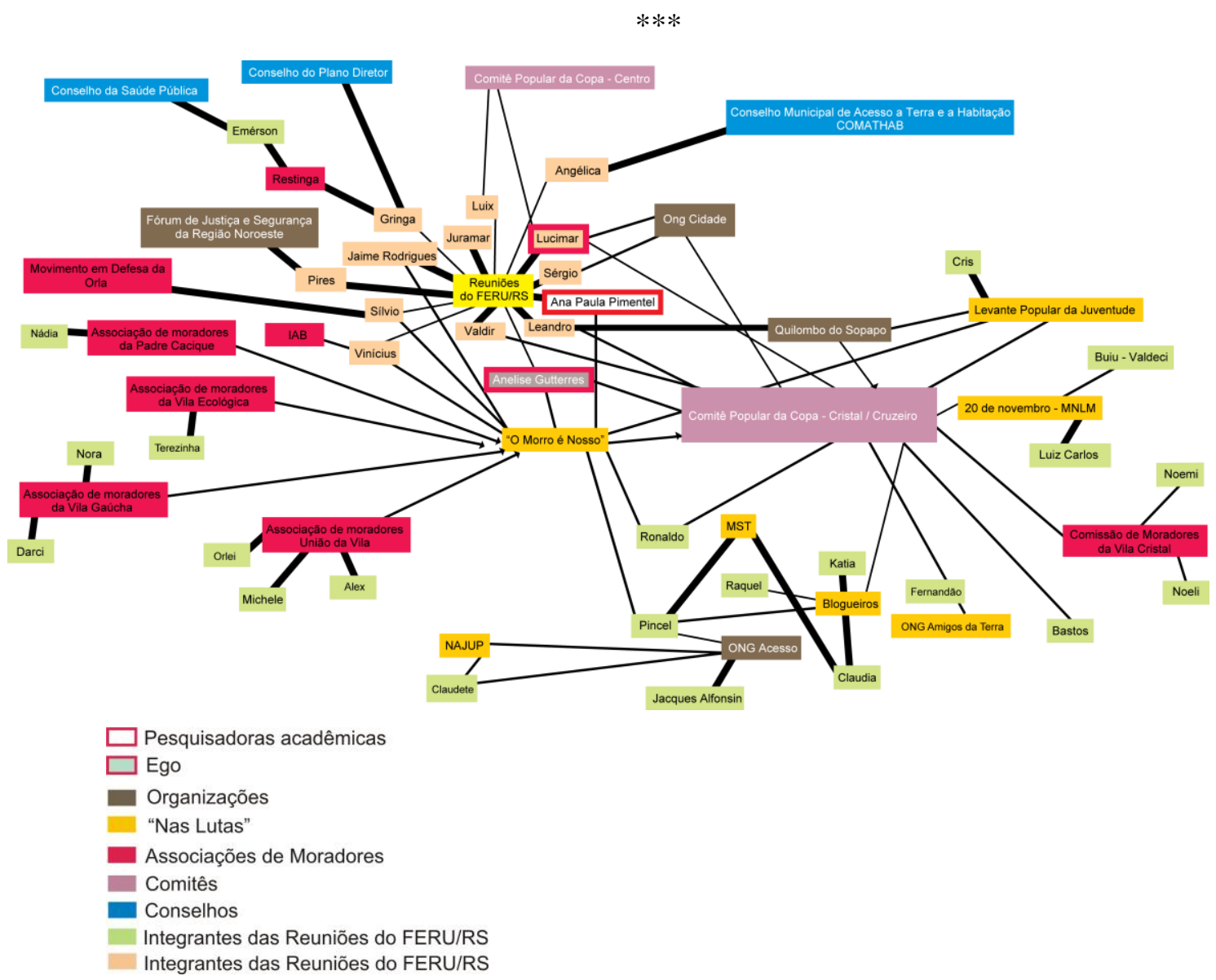

$* * *$

A rede aponta para uma estreita relação entre as diferentes escalas de poder governamental e como elas se articulam a partir de um debate local e situacional. As relações entre os atores mostram uma profunda intersecção entre diferentes níveis de organização política, onde se mesclam fundos de verba, intencionalidades e poder. Observando a região da margem esquerda da imagem da rede vemos um exemplo dessa inter relação, o MST, que é proprietário de uma metodologia para mobilização e formação de lideranças comunitárias e atua principalmente nas reuniões do "Morro é Nosso" tem como parceiro nesse movimento e no comitê da copa, o Levante Popular da Juventude, a ONG Acesso e o Quilombo do Sopapo.

A necessidade da organização como forma de se inserir numa escala de discussão política como a evidenciada pelo seminário dos megaprojetos é definidora também daqueles que participam desse debate. E a participação no debate, também não 
é garantia de que as demandas reclamadas sejam alcançadas. Muitos dos debates reunidos no seminário foram surgindo a partir da desarticulação do espaço político do $\mathrm{OP}$, fato constantemente retomado por alguns dos integrantes da reunião do morro e também nas reuniões do FERU/RS. Justificada pela mudança de partido político na ocupação da prefeitura do município de Porto Alegre, que ocorreu ao fim de dezesseis anos de PT, era anteriormente nesses espaços que as redes eram montadas. Como a maioria dos integrantes são ou eram militantes desse partido, naturalmente o fim do seu mandato e sua substituição pelo partido que assumiu a prefeitura, o PPS é também a decadência desse modelo de governo freqüentemente identificado pelo bordão de "popular e democrático". Descaracterizado, segundo a rede, o OP teria se transformado num exercício de clientelismo político dentro de suas regiões de atuação. A expressão "hay gobierno, soy a favor" proferida por Pincel, integrante do MST, em umas das reunião do morro, evoca a opinião geral sobre a atitude de líderes comunitários que assumiram cargos de conselheiros do orçamento participativo e que independente de causa, luta política, seguiam as diretrizes e o perfil do governo estabelecido. Não "lutavam" por suas comunidades, e aceitavam as negativas do governo e muitas vezes os benefícios que ele oferecia e isso apesar de uma prática frequente entre os lideres comunitários e moradores a cada novo ano de campanha política, era muito mal visto pelos integrantes da rede. No entanto esse mal visto também tinha suas contradições visto que um dos "companheiros" - categoria usada para identificar os integrantes da "luta", e da qual eu mesma, passei a ser chamada em campo - estava se preparando para assumir um cargo ligado ao poder estatal, já que o 2011 o governo passava a ser assumido novamente pelo PT, em seu âmbito estadual.

Os conflitos existentes nas reuniões do FERU/RS sobre como mobilizar a comunidade, metodologicamente e praticamente, como "fazer pressão", como "alertar sobre o que está acontecendo" personificavam e modelavam ações que tinham como propósito a conscientização dos moradores. Na região da Cruzeiro, na vila tronco e vila cristal, talvez seja onde essa dimensão conflitiva e pouco heterogênea na organização política de uma região e suas relações com o poder governamental, mais se apresenta. Nessa região há uma divisão clara entre associações de moradores que querem e que não querem sair do local, por trás desse conflito estão alguns vínculos com representantes políticos eleitos por voto.

Todos os integrantes ou militantes da região da Cruzeiro que integram a rede, pertencem ao comitê da copa que é contrário a atuação da associação de moradores da 
Vila tronco - Amavitron. Quando citado o presidente dessa associação era considerado uma liderança "vendida" que estaria aceitando a remoção porque já teria negociado benefícios próprios com os representantes eleitos para prefeitura. $\mathrm{O}$ teor dos benefícios somente alguns tinham conhecimento e você só tinha acesso a essas informações a medida que confirmasse na participação das reuniões e adesão a rede, que de fato você não pertencia ao "lado deles". Essas noções de legitimidade, honra e compromisso com a comunidade, agenciavam um conflito que de um lado tinha o partidarismo político de alguns líderes comunitários e movimentos políticos, simpatizantes, quando não militantes, do Partido dos Trabalhadores; e de outro lado as eleições políticas como uma possibilidade de trabalho, onde o partido pouco tinha relevância. Dialogando com as noções acima descritas e parte do conflito, o jogo das aprovações de projetos para a copa e a manutenção de uma cidade onde o cidadão tinha "voz" dependiam da inclusão de lideranças comunitárias como atores da construção "participativa" dos projetos. E eram uma exigência, algumas vezes, por parte das caixas e agências de financiamento público. Essa inclusão dos líderes expunha com mais clareza o conflito de interesses que estava em jogo nessas áreas, pois nem sempre o líder era representativo da comunidade, outras vezes a comunidade tampouco concordava com ele, e em outras ele nem mesmo morava mais na comunidade.

Na dinâmica das reuniões do FERU/RS, do movimento o morro é nosso e do comitê da copa, o caráter de auto-gestão que orienta as reuniões faz com que a presença nelas seja aquilo que fortalece os vínculos e a legitimidade da rede. Os traços mais grossos, que ligam os atores a suas instituições, remetem a consistência do vínculo com elas. Ao iniciar uma reunião é sempre o nome e a luta que são exigidas como apresentação pelo participante antes dos pontos serem narrados na pauta pelo coordenador do dia. A luta é o cartão que traduz de onde o sujeito está falando. Como as reuniões sempre têm novos atores isso se torna relevante, para que os mesmos - que já se conhecem e se reconhecem de outras lutas - mapeiem os estranhos. Essas lutas do passado podem ser das mais variadas, mas pelo que pude observar estão sempre ligadas à demanda de algum direito usurpado, negado ou não cumprido. A luta por algo é o palco dos discursos marginais sendo que para isso ela assume "bandeiras" das mais diversas. Não é raro que nas reuniões, “os povos”, “as mulheres”, “os índios” e "os negros", "os moradores" sejam agregados numa mesma categoria marginal, minoritária, sob a qual estariam todos ali reunidos, "na luta" em sua defesa. Essa marginalidade é 
produzida pelo próprio discurso e pelo próprio ato de reunião em pró de um direito ou de uma necessidade de fazer pressão a "eles" o governo, para defesa "deles" o povo.

O "povo" também é chamado de "eles" quando de dentro das reuniões reclamase de sua pouca participação ou pouco interesse em participar dos encontros e discussões coletivas na associação. A apatia reclamada pelos líderes ou integrantes de movimentos sociais aponta para uma lógica de organização política que se funda em concomitância às premissas da representatividade e da marginalidade. Há sempre alguém precisando ser salvo de sua própria condição e há sempre alguém querendo especular essa condição. O princípio de desigualdade e o da mudança é o que estimula esses atores a se reunirem toda a semana, muitas vezes, mais de uma vez por semana. Essa frequiência evidencia o caráter profissional que alguns atores tem com os encontros, ao mesmo tempo que evidencia a disponibilidade de tempo que um "morador" deve ter para estar na "luta".

\section{Conclusão}

Palavras como duplicação, revitalização, ampliação, reforma e transferências de famílias quase sempre integravam o discurso proferido pela prefeitura em defesa de uma cidade com mais visibilidade internacional, mais progresso, porém um progresso que "não esquece do bem estar social". No fim de 2010, o Demhab espalhou pela cidade várias propagandas em outdoor, onde anunciava que "a copa passa por aqui" junto a uma foto do novo loteamento da vila dique. Essa propaganda tinha intenção de divulgar o trabalho da autarquia na transferência da Vila Dique para a área da Avenida Bernardino Silveira Amorim, onde nem um terço das famílias moradoras da "velha Dique" haviam sido transferidas até realização deste ensaio.

No que tange as temporalidades e a relação delas com os níveis de internacionalização das relações e dos projetos de cidade, ressaltamos o caráter da globalização como um fenômeno que abrange esses atores em diferentes níveis. A contar que o Brasil e nele Porto Alegre já receberam uma copa do mundo, em 1950, nota-se que o discurso global - colocado na "especulação imobiliária", na luta pelos direitos humanos internacionais, e nos exemplos de eventos como esse em outras cidades "através do mundo" - pulula nas falas de atores. Alguns que nem mesmo circulam muito por sua própria cidade, e outros que já circularam em muitas outras cidades do mundo a partir dos seus vínculos políticos, evidenciam o hibridismo e a construção do discurso marginal (Tsing, 2002:5) em meio à circulação dos discursos e 
dos efeitos da globalização. No entanto, ressalto que a rede e espaço político aqui apresentados, transcendem essa dicotomia do global e do local. Nela são reunidas e articuladas lógicas que em seus vínculos produzem discursos híbridos que dificilmente poderia ser definidos somente através de uma comparação relacional. O discurso global do progresso e da urbanidade como uma obra da contemporaneidade utiliza, em sua intra-temporalidade narrativa uma imagem de progresso que discursivamente se aproxima da imagem nacional construída no período ditatorial brasileiro. Período onde o crescimento econômico e a relação com o global, muito mais de circulação de matérias do que de circulação de pessoas, já estava colocada em frases que requisitavam uma posição em relação à idéia de interação com o mundo: "Maracanã o maior estádio de futebol do mundo".

O progresso que consta nas páginas da prefeitura sobre os benefícios da copa do mundo para Porto Alegre, está presente no discurso dos militantes aliado a pergunta “pra quem?" e está presente no discurso dos moradores aliado a pergunta “para onde?". No caso das remoções necessárias as obras o poder municipal não hesita em usar a marginalidade para afirmar para si uma face mais humana a moeda da copa do mundo. Economicamente a idéia de progresso, também não sobreviveria sem a existência da categoria minoria. Sem a lógica da irregularidade não haveria necessidade de reassentamentos e sem ela a imagem de política social, do qual Porto Alegre ainda usufrui "internacionalmente", seria modificada e isso influiria inclusive nos investimentos internacionais que patrocinam ONGs com projetos ligados a cidadania e participação políticas na construção das cidades. Conforme Fortuna (1997), esse cenário transnacional de uma rede de cidades extrapola uma imagem local da região para em pró de uma mesma dimensão do localismo botá-lo em escalas globais de ingerência e política. O apelo do "social" muito influenciado pelo processo político que levou um ex-líder sindical a liderança do governo de uma federação de estados, torna-se uma moeda de troca evidenciada nos processos de negociação para realização da copa em Porto Alegre, já internacionalmente conhecida pelo Fórum Social Mundial. Dentro dessa imagem, a rede política acredita que a cidade ao realizar a copa estaria trocando sua identidade "social" por uma identidade globalizada que acabaria enfraquecendo a sua própria existência enquanto rede política. Entre discursividades e representações de estado, no contexto de Porto Alegre, a copa do mundo tornou-se uma aporia para discursos distintos sobre a relação entre cidade, progresso e marginalidade. E a política por sua vez, um campo intrínseco a formação de identidades sociais, práticas e vínculos 
entre os integrantes das diferentes esferas da rede que, em sua composição, vincula espaços políticos e poderes articulados pelo município, estado, movimentos sociais, comunidade e associações de moradores.

\section{Referências}

ALFONSIN, Betania de Moraes. Da invisibilidade à regularização fundiária: a trajetória legal da moradia de baixa renda em Porto Alegre-século XX. Dissertação (mestrado)-Universidade Federal do Rio Grande do Sul. Faculdade de Arquitetura, Porto Alegre, BR-RS, 2000.

BARNES, J.A. "Redes sociais e processo político". In: FELDMAN BIANCO, Bela. Antropologia das sociedades contemporâneas. São Paulo: Global, 1987. p. 159-193.

BEZERRA, Marcos Otávio. "Introdução" e "Conclusão". In: Em nome das "bases". Politica, favor e dependência pessoal. Rio de Janeiro: Relume\&Dumará, 1999. p. 9-30 e 255-265.

BHABHA, Homi. "DissemiNação. O tempo, a narrativa e as margens da nação moderna" e "O Pós-colonial e o Pós-moderno. A questão da agência". In: O local

da cultura. Belo Horizonte: Ed. UFMG, 1998. p. 198-238 e 239-273.

BOTT, Elizabeth. "Metodologia e técnicas de campo". In: Família e rede social. Rio de Janeiro: Francisco Alves, 1976. p 31-69.

CASTRO, João Paulo Macedo e. "Favela-Bairro" In: LIMA, Antônio Carlos de Souza (org.). 2002. Gestar e Gerir: estudos para uma antropologia da administração pública no Brasil. Rio de Janeiro: Relume Dumará. 316 p. (Coleção Antropologia da Política).

DAMO, Arlei Sander. "Cultura e agência: o engajamento no orçamento participativo" In: Campos: revista de antropologia social, vol. 9, n. 1. Curitiba: UFPR, 2008. p. 51-85. DURHAM, Eunice. A Caminho da Cidade - a Vida Rural e a Migração para São Paulo. São Paulo: Ed. Perspectiva, 1973.

ECKERT, Cornelia e ROCHA, Ana Luiza Carvalho da. O tempo e a cidade. Porto Alegre: Editora da UFRGS, 2005.

FEDOZZI, Luciano Joel. Cidadania e Cultura Política. Doze anos de governo participativo em Porto Alegre (1989-2000). Tese de Doutorado (Sociologia) - IFCH, Universidade Federal do Rio Grande do Sul, Porto Alegre, 2002.

FEE. Estrutura social e segmentação urbana na Região Metropolitana de Porto Alegre (RMPA), em 2000/ organização: Rosetta Mammarella, Tanya M. de Barcellos. - Porto Alegre: Fundação de Economia e Estatística Siegfried Emanuel Heuser, 2009. 346 p. (Documentos FEE, 67).

FERRETI, Rosemary Brum. Uma casa nas costas: análise do movimento social urbano em Porto Alegre. Porto Alegre: UFRGS, 1984. Dissertação (Mestrado em Ciências Sociais).

FORTES, Alexandre. "Nós do Quarto Distrito..." A classe trabalhadora portoalegrense e a Era Vargas. Tese de Doutorado (História) - IFCH, Universidade Estadual de Campinas, Campinas, 2001.

FORTUNA, Carlos José Cândido Guerreiro. Évora: Um caso de destradicionalização da imagem da cidade. Coimbra: Centro de Estudos Sociais, 1997.

GUPTA, Akhil \& FERGUSON, James. "Mais além da 'cultura': espaço, identidade e política da diferença” [1992]. In: ARANTES, A. A. (org.). In: Espaço da Diferença. Campinas: Ed. da Unicamp, 2000. p.30-49. 
LOMNITZ, Larissa Adler. "Redes informais de intercâmbio em sistemas formais" e "Sobrevivência em um bairro de periferia na Cidade do México". In: . Redes

Sociais, Cultura e Poder. Rio de Janeiro: E-Papers, 2009. p. 37-63 e 139-182.

PALMEIRA, M. G. S. Política, Facções e Voto. In: PALMEIRA, Moacir; GOLDMAN, Marcio. (Org.). Antropologia, Voto e Representação Política. Rio de Janeiro: Contra Capa, 1996, p. 41-56.

PALMEIRA, M. G. S. "Política e Tempo: nota exploratória". In: PEIRANO, Mariza. (Org.). O Dito e o Feito: Ensaio de Antropologia dos Rituais. Rio de Janeiro: Relume Dumará, 2001, p. 171-177.

PÓLVORA, Jacqueline Britto. Dispersions: Black Communities and Urban Segregation in Porto Alegre, Brazil. Presented to the Faculty of the Graduate School of The University of Texas at Austin for the Degree of Doctor of Philosophy, 2006.

ROCHA, Ana Luiza Carvalho da. "Coleções etnográficas, método de convergência e etnografia da duração: um espaço de problemas" In: Revista Iluminuras - Método e Interpretação na Construção de Narrativas Etnográficas, vol. 9, n. 21. Porto Alegre: PPGAS - UFRGS, 2008.

SAHLINS, Marshall. "Cosmologias do capitalismo: o setor transpacífico do sistema mundial". In: . Cultura na prática. Rio de Janeiro: Editora da UFRJ, 2004. p. 445501.

SANT'ANA, Maria Helena. Vila cai-cai: a lógica da habitação reciclável: estudo da organização do espaço e do tempo. Dissertação (mestrado) - Universidade Federal do Rio Grande do Sul. Instituto de Filosofia e Ciências Humanas. Programa de PósGraduação em Antropologia Social, Porto Alegre, BR-RS, 1997.

SHILLER, Nina Glick. "Transnationality". In: NUGENT, David e VINCENT, Joan. A Companion to the Anthropology of Politics. Oxford: Blackwell, 2007. p. 449-467.

SILVA, Marcelo Kunrath. "Sociedade civil e construção democrática: do maniqueísmo essencialista à abordagem relacional”. In: Sociologias, ano 8, n. 16, jul/dez. Porto Alegre: PPGS - UFRGS, 2006. p. 156-179.

SILVA, Roberto Antonio Capiotti da e ECKERT, Cornelia (orient.). "Cotidianos irregulares? Estudo antropológico da experiência de regularização fundiária junto aos moradores da Vila Batista Flores em Porto Alegre (RS)". In: Revista Iluminuras vol. 7, $\mathrm{n}^{\mathrm{o}}$ 15. Porto Alegre: PPGAS - UFRGS, 2006.

TSING, Anna. "Politics on periphery". In: VICENT, Joan. (Ed,). The Anthropology of politics. A reader in ethnography, theory and critique. Malden/Oxford: Blackwell, 2002. p. 323-337.

Sites

http://www.estadao.com.br/noticias/esportes,jose-serra-critica-exigencias-da-fifa-paraa-copa-de-2014,399844,0.htm

http://www.fifa.com/mm/document/tournament/competition/01/37/17/76/stadiumbook2

010_buch.pdf

http://www.portaltransparencia.gov.br/copa2014/porto-alegre/ 